MINERAL OCCURRENCES in the YUKON-TANANA REGION, ALASKA

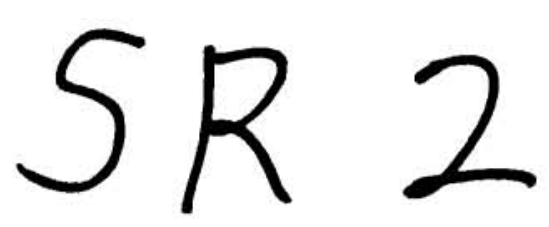

BY R. H. SAUNDERS

DIVISION OF MINES and MINERALS

DEPARTMENT OF NATURAL RESOURCES

STATE OF ALASKA

APRIL 1967 


\author{
STATE OF ALASKA \\ Walter J. Hickel - Governor \\ DEPARTMENT OF NATURAL RESOURCES \\ Phil R. Holdsworth - Commissioner \\ DIVISION OF MINES AND MINERALS \\ James A. Williams - Director
}

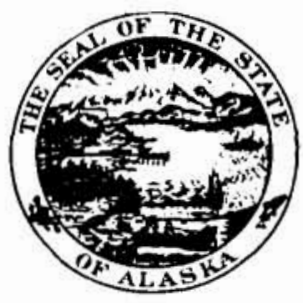

MINERAL OCCURRENCES IN THE YUKON-TANANA

REGION

By

R.H. Saunders

Juneau, Alaska

April, 1967 


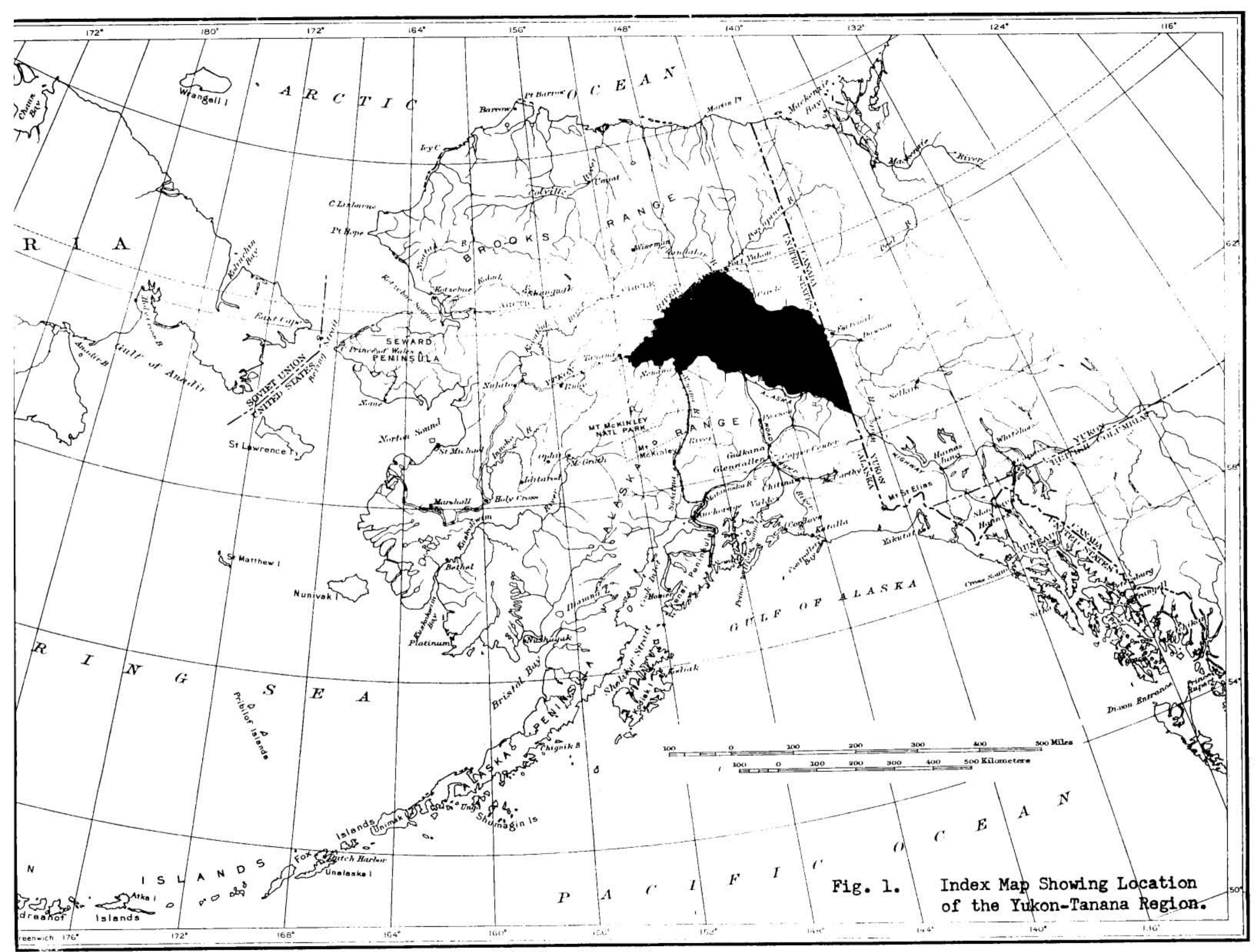




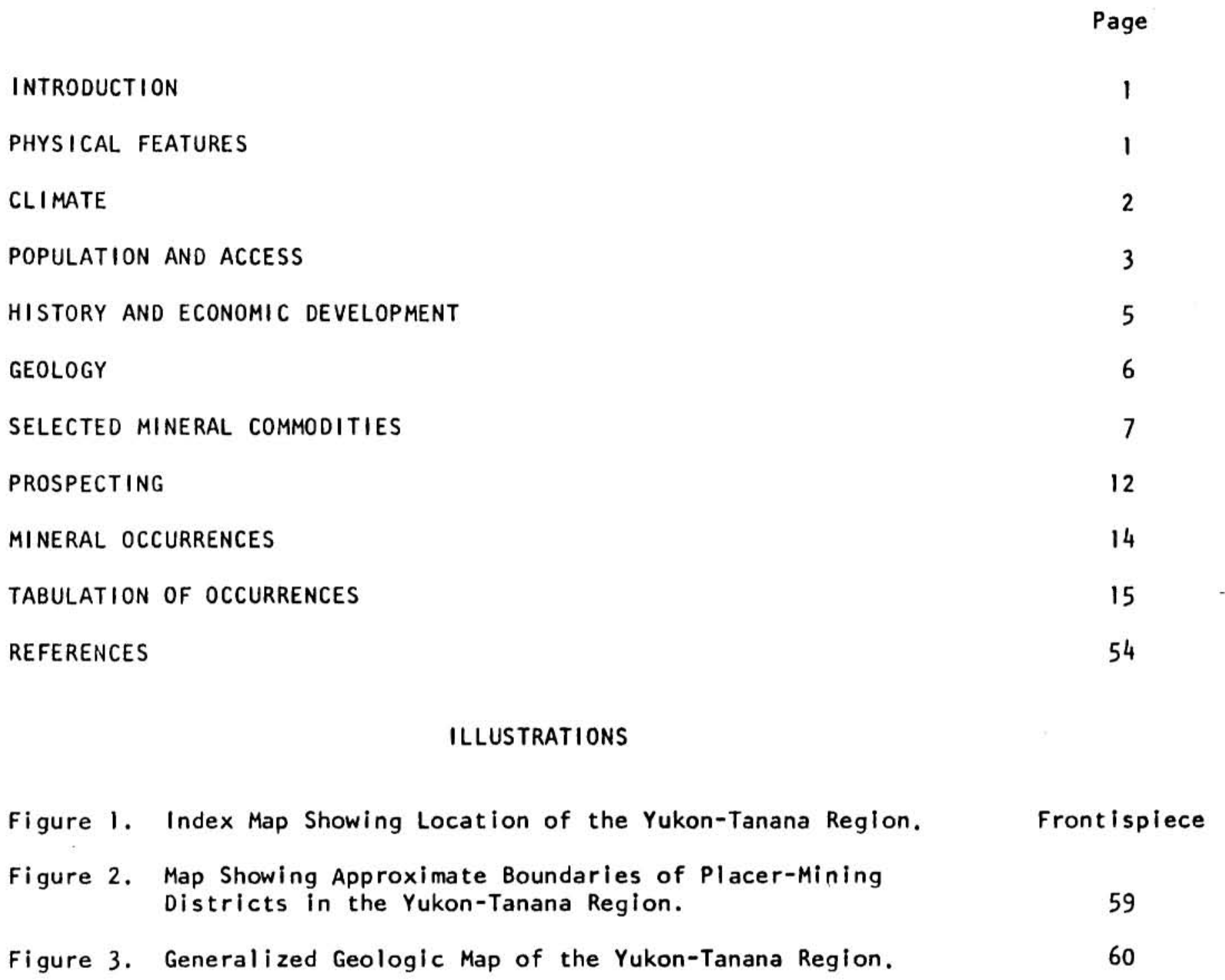


MINERAL OCCURRENCES III THE YUKON-TANANA

REGION

By

R.H. Saunders

\author{
INTRODUCTION
}

This report describes the Yukon-Tanana region with emphasis on those factors that pertain to mining and prospecting. It includes a tabulation of known mineral occurrences in the region. Only those occurrences that have been mentioned or described in literature are listed; although, in a few instances, the written sources are based solely on oral communication. Brief descriptions are given, where possible, so that the reader may know the general nature of each occurrence, and references are given for those who wish to obtain the more detailed information in the literature.

The mineral occurrences tabulated in this publication range in economic importance from particles that have been found in placer concentrates to deposits that have supported mines. The occurrences that appear to be economicaliy unimportant may be important as indicators of the nature and areal distribution of different kinds of mineralization. Each mineral deposit listed in the tabulation has been known by at least one prospector or geologist. Those of apparent economic importance have been explored to some degree; a few have been mined; many have been worked on and abandoned.

Most of the references cited in the tabulation are publicatiors of the United States Geological Survey. Many of these are now out of print, but offices of the Geological Survey and of the Division of Mines and Minerals have nearly complete collections that are available for public use. Some of the references cited are publications of the United States Bureau of Mines; some of these are also out of print, but may be available for public use at offices of the Bureau of Mines and of the Division of Mines and Minerals. Some of the out-of-print publications may be found in public libraries. Other references are published and unpublished reports of the Division of Mines and Minerals and its precedent agency, the Territorial Department of Mines. These reports may be inspected at offices of the Division. Still other references are unpublished theses at the University of Alaska; these are available for public inspection at the University.

\title{
PHYSICAL FEATURES
}

The Yukon-Tanana region comprises 38,000 square miles in east-central Alaska It is bounded on the northeast and northwest by the Yukon River, on the south by the Tanana River, and on the east by the International Boundary between the United States and Canada. The distance eastward across the region from the confluence of the two rivers to the International Boundary is 320 miles, and the greatest north-south width is 170 miles. Altitudes in the region range from about 200 feet above sea level at the mouth of the Tanana River to more than 6500 feet at the top of Mt. Harper, about 250 miles to the east. The uplands consist of rounded hills and ridges of nearly uniform height with a few discontinuous groups of mountains that rise above the ridge crests and hilltops. The uplands are higher in the eastern part of the region than in the western part; the valley floors are also higher; and the relief from east to 
west is about the same. Stream valleys are of diverse forms; some of the streams meander through broad valleys, and others are incised in gorges.

Three-fifths of the region is drained by the Yukon River and the remainder by the Tanana. The tributaries that drain the region are clear at normal water stages, but the Tanana River is heavily laden with silt from its glacier-fed tributaries that head in the Alaska Range. The Yukon River also receives some glacial debris from rivers that empty into it in Canada, but it normally carries less silt than the Tanana. The Yukon and Tanana are both navigable, the Tanana being more difficult to navigate because of its somewhat swifter current and its profusion of sand bars. The tributary rivers are also navigable, at least for small riverboats, through their lower courses.

The drainage history of the region is complex and is not yet well understood. In some districts remnants of ancient stream channels on ridgetops show the former existence of a drainage system of a different pattern from the present one. Backhand drainage in several places - Seventymile River, for example - also indicates that major changes have taken place in the drainage of the region. Great depths of alluvium underlying some streams show that the base level of erosion for part of the region has been elevated. Many valleys are abnormally large for the streams that flow through them - an indication that in some formertime the climate was less arid than it is now. Moraines and glacier-carved land forms at a few places in the higher country show the former presence of Alpine glaciers. There is no indication that a continental ice sheet ever covered the region.

The most abundant trees in the region are spruce, cottonwood, and birch; aspen and tamarack are common in some localities. In swampy areas and near timberline the spruce trees are small and scrubby, but in the lower valleys some are as large as two feet in diameter. Timberline is at 2500 to 3500 feet altitude. At the higher altitudes many of the steep slopes are covered by blocky talus. A variety of grasses and brush grows throughout the region, and in most places the cover of vegetation extends well above timberline.

\section{CLIMATE}

The Yukon-Tanana region has a sub-Arctic climate; the winters are long and cold, and the summers short and warm. Daylight is nearly continuous for about three months during late spring and early summer, and it lasts for only about two hours per day in late December. The region is semi-arid, having an average annual precipitation of about 11 inches; most of the rain falls during late summer. The average annual snowfall is about 50 inches, and about $13 \mathrm{l} / 2$ inches of snow in the region is equivalent to one inch of water. The lowest temperatures recorded have been about minus 70 degrees and the highest about 100 degrees Fahrenheit. The streams begin to freeze over in October, and the ice remains until late April or early May. Sluicing at placer mines can be done during about 120 days of the year. Seasonal frost in the ground can be expected to interfere with excavating until mid-July; much of the ground is permanently frozen. The higher parts of the region have fewer frost-free days than the lower areas, and high, north-facing slopes may be partly snow-covered until late summer.

In addition to the variation in daylight throughout the year, the climate has other features that may seem unusual to the newcomer. During a prolonged period of cold weather, a temperature inversion may make temperatures on hills and ridges higher than those on the adjacent valley floors. A hilltop dweller, therefore, escapes much of the extreme cold that the town residents in the lower valleys must endure. If a wind begins to blow, it upsets the inversion and brings warmer weather to the lower valleys. In the Fairbanks area, largely because of the concentration of fuel-burning equipment, 
ice fog accumulates during prolonged cold periods, limiting visibility, blocking whatever sunshine there may be, and, as a recent study has shown, creating a problem in air pollution. Winter temperatures vary widely; the highest temperature ever recorded for any given day of a winter month may be 100 degrees or more higher than the lowest temperature recorded for that day of the month. Summer temperatures also are subject to wide variation; the prospector planning a summer trip in the region should be prepared for temperatures ranging from 30 to 90 degrees.

\section{POPULATION AND ACCESS}

Fairbanks, with a population of about 14,000 , is the largest community in the Yukon-Tanana region. Suburbs and military bases near Fairbanks bring the total population of the Fairbanks district to about 44,000. Outside the Fairbanks district about 3000 people live in the region; most of them are along the roads and rivers in communities numbering fewer than 200 people in each.

The Richardson Highway links Fairbanks with Valdez, a year around port on the Gulf of Alaska. The highway is paved throughout its length of $364 \mathrm{miles,}$ and it is open all year, except for short periods during wind or snow storms in the winter. One hundred fifteen miles from Valdez the Richardson Highway is joined by the Glenn Highway from Anchorage. The Glenn and Richardson Highways provide a route 438 mi les long between Fairbanks and Anchorage. The Glenn Highway is paved and is open the year around, except possibly during winter storms. At Delta Junction, about 100 miles from Fairbanks, the Richardson Highway is joined by the Alaska Highway. This highway links the road net of Alaska with that of western Canada and provides the only overland route between Alaska and the conterminous states. It enters Alaska in the upper Tanana valley and approximately parallels the Tanana River to Delta Junction. The Alaska Highway is open the year around, and the nart within Alaska is paved. The distance by road from Dawson Creek, B.C., to Fairbanks is 1520 miles, and from Seattle to Fairbanks, 2360 miles.

Some of the settlements within the Yukon-Tanana region are connected by roads. The Fairbanks-Nenana road, a partly paved road $60 \mathrm{miles}$ long, is open all year. This road, within a few years, will be part of a new highway link between Fairbanks and Anchorage that will be about 100 miles shorter than the route over the Glenn and Richardson Highways. The Steese Highway goes from Fairbanks to Circle ( 162 miles), and a branch road from it links Fairbanks with Circle Hot Springs ( 136 miles from Fairbanks). The Steese Highway is paved from Fairbanks to Fox (11 miles). In the winter only the 30-mile length of the highway at the Fairbanks end is maintained. The Elliot Highway goes from Fox to Livengood ( $74 \mathrm{miles)}$ and Manley Hot Springs (149 miles). It is a gravel road, and it is not maintained in the winter. The Taylor Highway goes from Tetlin Junction on the Alaska Highway to Eagle on the Yukon River (158 miles). A branch from this highway goes to Dawson, Yukon Territory. The Taylor Highway is a gravel road, and it is not maintained in the winter. Another road, now under construction, will extend from the Steese Highway near Fairbanks up the Chena River valley to Chena Hot Springs (about 60 miles from Fairbanks). A few other short roads have been built in the Fairbanks district to provide access to areas where people have settled. The roads in the Yukon-Tanana region that are not passable the year around are open to travel from early June to mid-October.

The Alaska Railroad provides rail transportation between the Yukon-Tanana region and seaports at Anchorage and Seward. Fairbanks is the northern terminus of the railroad. The distance by rail from Fairbanks to Nenana is 58 miles; to Anchorage, 358 miles and to Seward, 470 miles. 
A hydrotrain and other unitized cargo equipment have been in service to and within Alaska during the past few years. Freight rates for carload lots from Seattle to Fairbanks range from $\$ 1.63$ per hundred pounds for groceries in 50-ton lots to $\$ 3.08$ per hundred pounds for petroleum products in 30-ton lots. Ores and concentrates can be shipped from Fairbanks to Seattle for as little as $\$ 1.23$ per hundred pounds; the rates vary depending upon the amount shipped and the value of the ore or concentrate. Higher rates are charged for less-than-carload lots.

Fairbanks has two airports: the Fairbanks International Airport, which is large enough for long-range aircraft, and Phillips Field, which is used by small aircraft. Small airfields in the region are at Manley Hot Springs, Rampart, Circle, Central, Circle Hot Springs, Eagle, Chicken, Eureka, and Livengood. Other landing strips have been built at various places, but some of them have become unusable because of erosion or the growth of brush or trees. Commercial pilots who fly to the outlying districts are usually the best sources of information on the condition of the "bushrairstrips.

The rivers provide routes for freighting to some of the outlying communities. The freight goes by rail or truck to Nenana or Fairbanks, where it is transferred to boats or barges. In former years many passengers traveled by riverboat, but now the only passenger travel is on local pleasure cruises that start from, and return to, Fairbanks. Small riverboats are commonly used by prospectors, hunters, and fishermen; most of these are flat-bottomed boats up to 35 feet long propelled by outboard motors. They are used in the tributary streams as well as in the Yukon and Tanana Rivers.

Prospectors necessarily must be concerned with cross-country travel away from roads, rivers, and airfields. In many instances helicopters provide the most satisfactory means of transporting prospectors and their supplies. The cost per hour of helicopter charter is high, but the saving in time and trouble can be well worth the cost. Ordinarily, Fairbanks is the only place in the region where helicopters can be chartered. Four-wheel-drive vehicles can be used to good advantage, but their use generally must be restricted to roads, trails, and the crests of some ridges. Recently, motorcycletype trail machines have been used in the region. Their use, too, is limited, but they can travel some terrain not passable for four-wheel-drive vehicles. In the winter, wheeled vehicles can be used only on maintained roads.

Crawler-mounted equipment of various types has been used for cross-country travel in both summer and winter. These machines can travel most of the terrain, but the routes of travel must be selected carefully. If heavy freighting is to be done, it can best be done in late winter and early spring with sleds and crawler-type tractors. In a few instances temporary winter roads have been built with tractors; and conventiona two-wheel-drive trucks have been driven over them.

Dog teams and sleds have been the traditional means of winter travel in the North. Dogs also have been used for packing in the summer, but they are unable to carry loads as large as those they can pull on sleds. Recently, snow mobiles have become popular in the region; so far, most of them have been used for recreation, but they, too, may be useful to the prospector. Supplies for a summer's prospecting may be freighted during the preceding winter and stored in caches. If no better means of travel can be arranged, the prospector can resort to back-packing. For most backpackers, the enjoyment to be derived from a long trip will be greater if periodic airdrops along the route can be arranged. 
The earliest explorations of the Yukon-Tanana region were made by officials of the Hudson Bay Company, who entered the region by way of the Yukon and Porcupine Rivers as early as 1842. In 1847 the Hudson Bay Company established a trading post at Fort Yukon not realizing that the site was in Alaska, which, of course, was then owned by Russia. The first authentic report of a gold discovery in the region was that of a discovery made by a missionary in the Circle district in 1863. No attempt was made to mine the gold. Many years later prospectors applied the name "Preacher Creek" to a tributary of Birch Creek in the belief that the discovery was made there; the name is still in use. In 1866 an expedition of the Western Union Telegraph Company traveled by boat from the mouth of the Yukon River to Fort Yukon, and two members of the expedition continued on to Fort Selkirk in Canada. In 1869 an expedition led by Captain Charles Raymond, U.S. Army, traveled up the Yukon River and determined the geographic position of Fort Yukon; whereupon the Hudson Bay Company abandoned its post there and established another trading post on the upper Porcupine River. In the early 1370's a few prospectors and traders entered the region from the Yukon Territory and, during the next 25 years, made exploring trips into various parts of the region. The best known men in this group were Arthur Harper and Jack McQuesten. In 1882 the Schiefflin brothers of San Francisco, who where the discoverers of ore deposits at Tombstone, Arizona, traveled up the Yukon in a small steamboat and discovered gold about $80 \mathrm{miles}$ above Tanana. They returned to San Francisco in 1883 and did not follow up their discoveries. In 1883 a U.S. Army expedition led by Lieutenant Frederick Schwatka crossed Chilkoot Pass and rafted from the headwaters of the Yukon to its mouth; this party made the first actual survey of the Yukon River.

In 1886 gold was discovered in the Fortymile district on Franklin Creek, and this was the first discovery in the region to lead to the establishment of a mining camp. Discoveries were made at Rampart and $\mathrm{Ci}$ icle in 1893 and on American Creek in the Eagle district in 1895. Small mining camps grew in each of these places, and, when gold was discovered in 1896 in the Klondike district in Canada, about 1000 men already were engaged in mining in Alaska. Many of them joined the rush to the Klondike when news of that discovery spread through the Alaskan camps. The Klondike discovery attracted thousands of gold seekers; some of the later arrivals, unable to acquire rich ground in the Klondike moved into Alaska to prospect. Several important discoveries were made, and some of these led to the development of more mining camps in the Yukon-Tanana region: Manley Hot Springs in 1898, Fairbanks in 1902, Richardson in 1905, and Livengood in 1914.

Placer mining flourished until 1916. By that time the richest of the easily worked placers were exhausted, and the inflated wartime prices discouraged gold mining ventures. Military service and other wartime activities caused an exodus of men from Alaska. During the war scheelite and stibnite were mined from a few properties in the Fairbanks district, and tin was recovered as a by-product of gold mining in the Manley Hot Springs district.

After World War I, gold production continued to decline until the late 1920's, when a large dredging operation in the Fairbanks district become productive. During the depression years gold mining expanded rapidly, and the resurgence of mining activity continued until World War II. Prior to World War II, gold mining and the fur trade provided the economic base for the Yukon-Tanana region. Other types of business ventures grew to satisfy local demands, but the money that circulated in the region came in only. through the export and sale of gold and fur. During World War 11 gold mining and trapping declined sharply. In spite of this decrease in its former economic base, the region grew rapidly in both population and overall economic activity. The construction and operation of military bases and other government-financed facilities became the new economic base for the region. 
Between World War 11 anu the Korean War, mining revived to a small degree, partly because war surplus equipment that could be adapted to placer mining became available at moderate prices. Lode-gold mining remained almost totally inactive. Since the Korean War placer mining has declined continually, and mining now accounts for only a small part of the economic activity in the region.

One of the striking changes that came with the new economy was a shift of opportuniti for employment from outlying areas to the Fairbanks area. While Fairbanks grew from a mining town to a modern city, several outlying settlements were abandoned. In some of the old recording districts the duties of recorder passed from person to person until no one qualified and willing to do the work remained. Recording offices at Livengood, Circle and Eagle were closed; the records were sent to Fairbanks; and the old recording districts became a part of the Fairbanks Recording District. Few opportunities for employment now exist in the region outside the Fairbanks area, and the concentration of the region's economic activity in that area is reflected in the distribution of the population. The present economy of the Yukon-Tanana region is essentially the economy of the Fairbanks area.

In 1964 more than 40 percent of the total number of persons employed in the Fairbanks area were employed by federal, state, and local government agencies.* More than 30 percent were employed by construction, trade, and service industries, * which, directly or indirectly, were also largely dependent upon government spending. Placer mines in the region employ 60 to 70 men each summer, and 5 to 10 men are employed in lode mining or lod, mine development. Records of the Division of Mines and Minerals list 20 active prospector: in the region in 1965; however, not all prospectors are included in any official listing.

Government activities in the Fairbanks area are of various types. Military bases, missile detection facilities, arctic and space research installations, and the University o Alaska all play an important part in the economy. Tourism also accounts for part of the economic activity, and its importance is increasing. Fairbanks, being the trading center for much of northern Alaska and all of Interior Alaska, derives some economic gain from activities outside the Yukon-Tanana region. Currently, a large amount of freight is being moved eacn year from Fairbanks to sites of oil exploration activity on the north coast.

\section{GEOLOGY}

Several bulletins describing the geology of parts of the Yukon-Tanana region have bee published by the United States Geological Survey. The titles of these are included herein in the list of references following the tabulation of mineraloccurrences. U.S. Geological Survey Bulletin 872, THE YUKON-TANANA REGION, ALASKA, by J.B. Mertie, Jr., 1937, summarize the information contained in earlier reports. It describes the general rock types present and $i t$ includes a map of the region that shows the distribution of the major geologic units. Bulletin 872 gives the most nearly complete description of the geology of the Yukon Tanana region that has been published. It is now out of print; however, anyone planning to prospect in the region should obtain a copy, if it is at all possible to do so.

*REVIEW OF BUSINESS AND ECONOMIC CONDITIONS, University of Alaska, Institute of Business, Economic, and Government Research. July, 1965. 
Most of the geologic mapping that has been done in the reqion was done before aerial photographs and helicopters were available to geolonists. Even if the region were re-mapped with the most modern equipment, the heavy cover over most of the country would necessitate a good deal of inference and extrapolation. Therefore, it is to be expected that many details of the geology are not shown on the published maps.

Much of the Yukon-Tanana region is underlain by crystalline schists (the Birch Creek schist formation), which Mertie considered to be of pre-Cambrian age. There is doubt now as to the age of this formation, and it may be, at least in part, younger than pre-Cambrian.

Any attempt here to describe the geology of the region necessarily would be a repetition of what already has been published in Bulletin 072 . Figure 3 is a generalized geologic map adapted from maps published by the United States Geoloqical Survey.

\section{SELECTED MINERAL COMMODITIES}

Antimony. Stibnite (a sulfide of antimony) is widespread throughout the Yukon-Tanana region. It is a constituent of most of the gold-bearing quartz veins in the Fairbanks district, and it also has been found in veins and shear zones that carry little or no gold. It occurs disseminated through the veins and shear zones and also in the form of lenses, kidneys, and irregular masses. About 2500 tons of stibnite has been produced in the Fairbanks district - most of it was mined from the Scrafford property (Map No. 135). About 500 tons has been mined from a deposit on Sawtooth Mountain in the Rampart district (Map No. 19). Most of the deposits that have been mined have been small, and all of them nave been high enough in grade to permit shipping of the ore with no concentrating other than hand-sorting. The mining has been done during periods of exceptionally high prices - usually in wartime. A few instances have been reported in which prospectors have found stibnite but have not staked or worked on the deposits, because the market was unfavorable when the finds were made.

Bismuth. No important deposits of bismuth are known in the Yukon-Tanana region. Native bismuth has been reported on No Grub and Caribou Creeks, tributaries to Salcha River. Native bismuth and bismuthinite have been found in gold-quartz in the headwaters of Fish Creek in the Fairbanks district. Native bismuth also has been identified in placer concentrate from Ruby Creek in the Rampart district.

Chromium. In the Tolovana district and in the Salcha River drainage, chromium has been found disseminated through ultramafic rocks. It also has been detected in placer concentrates from streams draining areas where ultramafic rocks are known. During periods of national emergency, the United States government has purchased chromium ores at incentive prices from donestic producers. Usually, however, the United States imports nearly all the chromium it uses. Prices of chromium ores landed at east coast ports from foreign sources currently range from $\$ 18$ to $\$ 33.50$ per long ton. Its low price would preclude the mining of chromium in the Yukon-Tanana region under usual market conditions. 
Cobalt. Cobalt has been reported in two places in the Yukon-Tanana region: at the Barrett prospect in the Manley Hot Springs district, where it is in a complex assemblage of metallic sulfides, and at the Jenkins prospect near Eagle, where it accompanies nickel and copper sulfides.

Copper. Several copper prospects are known in the Fortymile and Eagle district. Few of them appear to have much promise, but some of the better ones are in remote areas where exploration costs would be high, and they have had little or no work done on them. Copper minerals are a part of the mineral assemblage at the Barrett prospect in the Manley Hot Springs district. Native copper nuggets have been found on several creeks in the Rampart district and on Sullivan Creek in the Manley Hot Springs district. Chalcopyrite has been found in placer concentrate from Portage Creek in the Circle district, and trace amounts of copper have been detected in gold-quartz veins in the Fairbanks district.

Gold. The Yukon-Tanana region includes eight well known placer-mining districts. The total production of placer gold in the region has been about ten million ounces, and the production of the various districts through 1960 was:

$\begin{array}{lcc}\text { Fairbanks } & - & 7,500,000 \text { ounces } \\ \text { Circle } & - & 730,000 \\ \text { Manley Hot Springs } & & 450,000 \\ \text { Fortymile } & & 410,000 \\ \text { Tolovana } & - & 380,000 \\ \text { Rampart, Eagle, and Richardson } & - & 170,000\end{array}$

The trend of gold production in the region since World War 11 has been the same as in other gold-producing areas in the United States. After the war gold mining was resumed, and by 1950 Alaska's annual production had increased to equal 40 percent of the pre-war rate. Siı:ce then, however, production has declined almost continuously, and the current rate of production is equivalent to about six percent of the pre-war rate. This drastic reduction has not been caused by the exhaustion of gold deposits; it is instead the result of maintaining a fixed price for gold during a period of continual monetary inflation. The decline can be expected to continue unless a major change occurs in the relationship between the price of gold and the purchasing power of the currency.

The areas in the region that have been placer mined are shown in red on the accompanying maps. The gold mineralization is considered to have been associated with the intrusion of granitic rocks, and the sites of mineral deposition were near the peripheries of the smaller intrusions. In some areas tiny veinlets, too narrow and too widely spaced to be minable, appear to have been the bedrock source of gold in the placers.

In most placer deposits the main concentration of gold is in the gravel immediately overlying bedrock. The first discoveries in the region were made where bedrock was either exposed or near the surface, and the earliest mining was done in shallow open cuts by shovelinginto sluice boxes. Steam-powered excavators and equipment for hydraulickingsoon were brought $i n$, and more efficient methods that had been developed in other gold fields were adapted to the Alaskan placers. In some districts, notably at Fairbanks and Livengood, paystreaks were found in deep ground, where open-cut mining was not feasible; there, shafts were sunk to bedrock, and the placers were mined by an underground method known as "drift mining." Horizontal workings (drifts) were driven from the bottom of each shaft along the top of bedrock, and rooms were excavated starting at the ends of the drifts and retreating toward the shaft; the method used was somewhat 
similar to the coal miner's method of "longwall retreating." As mining progressed the workings usually filled in behind the miners through settling, caving, or sloughing of the overlying gravel. Picks and shovels were used for digging and loading, and wheelbarrows were used for transporting the gravel to the bottom of the shaft, where it was dumped into a bucket to be hoisted, usually by a steam-powered hoist. At the surface the gravel was dumped directly into a sluice or into a storage pile (winter dump) depending upon the time of year. Winter dumps were sluiced during the spring run-off, and many drift mines were operated all year.

Most of the placers were permanently frozen. This was an advantage in that it enabled the miners to drive underground workings with little or no timbering, but it was a disadvantage in that it necessitated thawing the gravel in order to mine it. In the earliest drift mining in the North, thawing was done with wood fires. Not only was this inefficient, but the smoke in poorly ventilated underground workings was hazardous. A method of putting stream or hot water into the ground through pipes called "points" was devised; the first "points" are reported to have been fashioned from rifle barrels.

Dredging was introduced in Alaska shortly after the first gold discoveries were made. Attempts to dredge permanently frozen ground without first thawing it were failures, but some of the early dredging ventures in ground free, or partly free, from permafrost were successful. At a few of the early dredging operations frozen ground was thawed with steam, but the cost of steam thawing was too high to permit the practice to become widespread. Where the gravel to be dredged was not too thick, the ground would thaw naturally if stripped of silt and moss and left exposed for two or three years. The success of dredging in deep frozen ground required the development of a more economical method of thawing, and a suitable method using unheated water as a thawing medium was developed by 1920. In 1941 sixteen dredges were digging in the Yukon-Tanana region - one at Livengood, two in the Fortymile district, three in the Circle disirict, and ten in the Fairbanks district. Small-scale placer mining in the region also increased during the two decades preceding World War 11 ; the first part of the increase came as bulldozers and draglines were applied to small open-pit mines, and a further increase in activity came when the price of gold was raised in 1934.

The first lode claim in the region was staked in the Fairbanks district in 1903 , and the district underwent a flurry of interest in lode-gold prospecting and mining during 1908 to 1913. A second period of intense interest in lodes in the Fairbanks district came in 1923, after the completion of the Alaska Railroad; and a third period followed the increase in the price of gold in 1934. Other placer districts in the region have been subjected to some lode prospecting, but they have not been prospected for lodes as intensely as has the Fairbanks district.

Lode-gold production in the Yukon-Tanana region has been about $\$ 7 \mathrm{million}$, and nearly all of it has come from the Fairbanks district. Prior to World War II the rate of lode-gold production in the district reached nearly a half million dollars per year. Most of the productive veins were only 10 to 18 inches wide, and, in mining such narrow veins, it was necessary to break barren wall rock in order to have working room in the stopes. The lode mines were not mechanized to any great degree - most mechanical equipment cannot be adapted to mining in narrow underground workings as readily as in wider workings. Although mechanical loaders have been used in some exploration work since the war, in pre-war years ore was shovelled by hand into chutes and mine cars. The mining method most commonly used was a form of cut-and-fill stoping known as "resuing." Open stopes with irregularly spaced stulls for wall support were worked on a few of the wider veins; in most places, however, the schist wallrock did not stand well enough to permit any form of open stoping. 
In the veins that have been mined for gold, metallic sulfides have constituted less than two percent of the vein naterial in most places; but irregular masses of metallic sulfides, some large enough to contain several tons, have been encountered. The most common sulfides are arsenoovrite, jamesonite, stibnite, pyrite, galena, and sphalerite. Arsenopyrite and jamesonite are fairly reliable indicators of gold mineralization. b'here exposed in outcrops or excavations the gold-bearing veins ordinarily can be recognized by a characteristic staining of yellow, green, red, and brown from the oxidation of sulfides containing arsenic, antimony, and iron. The staining, however, does not necessarily indicate that the veins contain enough gold to be minable. The gangue is almost entirely quartz; calcite has been found in some veins, but it is rare. The wallrock of most of the veins is the Birch Creek schist formation, but a few veins in intrusive rocks are known. Quartzitic members of the Birch Creek formation are generally better host rocks for veins than the softer micaceous members, because the veins tend to finger out in the softer rock. Folds apparently provided structural control for the mineralization; most of the veins are near the crests of anticlines, and they tend to parallel the anticlinal axes. Numerous post-ore faults add to the uncertainties of mining. Some of the veins were mined over distances of a few thousands of feet along the strike and a few hundreds of feet down the dip.

Development work was done on one promising lode deposit reported to have a minable width of more than 20 feet, but the development was still in progress when World War II began, and the property was not put into production. Other wide lodes are known; a few were mined over widths reported to be as much as 12 feet, but most were too lowgrade to be mined, even under pre-war conditions. The lodes are fracture zones in which closely spaced quartz veinlets are separated by silicified schist.

More than a dozen mills have been built in the Fairbanks district, but probably not all were in use at any one time. The largest had a capacity of only 20 tons per day. Primary crushing was done in jaw crushers; stamps were used for fine grinding at most of the mills, but Chilean-type mill:, ball mills, and rod mills also were used. Most of the ores that have been mined have been 80 to 85 percent free-milling. Most of the mills relied entirely on amalgamation for recovery, but at two of the most productive properties gold was recovered by both amalgamation and flotation.

In recent years no lode mines have operated continuously, but a small amount of gold has been produced by small-scale, intermittent, lode operations.

Lead. Galena (lead sulfide) has been reported in placer concentrates from several places in the region. It breaks into fine particles readily when subjected to abrasion in streams, and it decomposes readily into earthy secondary minerals in weathering processes. It therefore may be more abundant and more widespread than the placer concentrates indicate. The unit value of lead is too low to permit the mining in the region of galena with no silver. Much of the galena that has been found, however, has carried appreciable amounts of silver.

Mercury. Mercury in the form of cinnabar has been found in placer concentrates in the Manley Hot Springs, Rampart, Tolovana, Fortymile, and Eagle districts. It is particularly abundant in placers on Olive Creek in the Tolovana district, and some work has been done on a lode prospect near the head of that creek. It is also abundant in placers on Canyon Creek, tributary to Seventymile River, but no bedrock source has been found in the Canyon Creek drainage. 
Molybdenum. Except for small amounts of molybdenum in tungsten prospects in the Fairbanks district, the only known occurrences of molybdenum in the Yukon-Tanana region are in the vicinity of Mt. Harper at the head of Goodpaster River. High-grade specimens of molybdenum were reported to have come from the vicinity of Tanacross, but the exact location where they were found is not known.

Nickel. A few nickel prospects have been found in the Yukon-Tanana region. They are in or near ultramafic rocks. Two bands of rock that include ultramafics of Devonian age cross parts of the region. One band extends northeasterly across the Livengood quadrangle from the West Fork of Tolovana River to Beaver Creek, north of the White Mountains. The other band trends easterly across the Salcha River drainage; it is cut off by the "Charley River batholith" (a large granitic intrusion), but on the east side of the batholith small disconnected bodies of the same type of rock are scattered down the south side of Seventymile River and across the Yukon River at Eagle. Some of the Paleozoic map units include ultramafic intrusives that have not been mapped separately. So far, the known prospects appear to be below minable grade.

Platinum. The only reported occurrences of platinum in the Yukon-Tanana region are on Lucky Gulch, tributary to Seventymile River, Eagle district, where it has been found in small amounts in placer concentrate, and in the Salcha River drainage, where it has been reported in trace amounts in serpentine.

Silver. Most of the silver that has been produced in the Yukon-Tanana region has been a by-product of gold mining. A small amount, however, has been produced from deposits of silver-bearing galena in the Fairbanks district, and silver-bearing galena has been reported in other districts. The galena deposits that have been mined have been small lenses, pods, or kidneys. The ores have been hand-sorted, and most of the galena that has been shipped has contained 50 ounces or more of silver per ton. During most of the years since mining began in the region, the price of silver has not been high enough to provide mucil incentive for prospectors to search for silver-lead deposits. Silver now commands a high price, and most authorities are predicting that the price will go higher.

Tin. Tin in the form of cassiterite has been identified in placer concentrates in all the mining districts in the Yukon-Tanana region. It is particularly abundant in a twelve-mile-long belt in the Manley Hot Springs district commonly called the Tofty tin belt. The belt is about one mile wide, and it extends northeasterly from lower Woodchopper Creek across the drainaqe basin of Patterson Creek into the upper drainage of Baker Creek. It includes all or part of the valleys of twelve streams or gulches (from Woodchopper Creek to Killarney Creek) that are tributary to either Patterson Creek or Baker Creek. Placer mines in the belt have produced 470,157 pounds of cassiterite as a by-product of gold mining. Sluicing practice at these mining operations has been better for the recovery of gold than for the recovery of cassiterite. The U.S. Bureau of Mines has estimated that tailing piles along the belt contain 733,000 pounds of tin.* Cassiterite also is abundant in placer concentrates from several creeks in the Circle district. Cassiterite in gold-quartz veins has been reported in the Circle and Fairbanks districts, but none of the known lode occurrences appear to be economically important.

Tungsten. Tungsten minerals have been found in placer concentrates throughout the region. Both scheelite and wolframite have been identified, scheelite being more common and more widespread than wolframite. The most important lode prospects that

*Thomas, Bruce 1., 1957, TIN BEARING PLACER DEPOSITS NEAR TOFTY, HOT SPRINGS DISTRICT CENTRAL ALASKA: U.S. Bureau of Mines Rept. Inv. 5373, 56 pp. 
have been found are replacement deposits in limestone or lime-rich rocks near granitlc intrusives. Scheelite also has been found in some gold-quartz veins in the Fairbanks district. During the two World Wars 4000 units of tungsten trioxide (20 pounds per unit) were produced from the Stepovich lode on Gilmore Dome in the Fairbanks district.

Zinc. In the Yukon-Tanana region no deposits are known that are valuable chiefly for their zinc content. The low unit value of zinc would preclude the mining of zinc deposits in the region, unless they contained other more valuable metals. Sphalerite (zinc sulfide) accompanies other metallic sulfides in a limestone replacement deposit at the Westonvitch prospect (Map No. 190) in the Fairbanks district. Sphalterite also is common in gold-quartz veins in the Fairbanks district, but in such fine particles that it seldom can be recognized without a microscope. Because of its common association with other metals, its mobility in the zone of weathering, and its easy detection in geochemical tests, zinc may prove to be important in the region as an indicator of valuable mineral deposits.

Nonmetallic minerals. A few nonmetallic minerals are mined in the Yukon-Tanana region for local use - mostly in the Fairbanks area. Peat is used as a soil additive for lawns and gardens. A small amount of stone is quarried from time to time for decorative facing in the construction of homes and buildings. Sand and gravel have been used in large amounts since construction became a major part of the region's economy. Dredge taillngs have been a source of some of the sand and gravel used in the Fairbanks district.

The recent discovery and development of an asbestos deposit in Canada a short distance east of the Fortymile district caused some interest in searching for asbestos on the Alaskan side of the boundary, but so far only tiny veinlets of asbestos too narrow to be mined have been found in the Fortymile district. A few asbestos fibers were found in limestone rubble near Fox in the Fairbanks district.

\title{
PROSPECTING
}

The favorability of any region for prospecting depends partlyon how thoroughly that region has already been prospected. In regard to prospecting for placer gold in the Yukon-Tanana region, Mertie, in 1937, wrote:

\begin{abstract}
"A great deal of placer prospecting has been done in the YukonTanana region in the last 40 years, but when the amount of such work is considered in relation to the great area of the region, it ceases to be so significant. It is probably true that no new placer-mining areas as large as the Fairbanks district are likely to be discovered in this region, because even the amount of prospecting so far done has probably sufficed to locate these major areas of mineralization. But the writer is firmly convinced that smaller mining areas, where the gold placers are localized mainly in one valley, are likely to be discovered from time to time as prospecting continues."
\end{abstract}

Since 1937 little prospecting has been done in the region. Because mining costs have increased, some placer-gold deposits that would have been minable in $1937 \mathrm{might}$ not be minable now. Mertie's opinion is still valid, provided that allowances are made for the change in economic conditions. Obviously, most of the prospecting that has been done in the region has been placer prospecting. With the exception of a small area near the head of Goodpaster River, the Fairbanks district is the only part of the region that has been subjected to much lode prospecting.

*Mertie, J.B., Jr., 1937, THE YUKON-TANANA REGION, ALASKA: U.S. Geological Survey Bulletin 872 ; pg. 267. 
Although the early-day prospectors were interested primarily in placer-gold deposits, it should not be assumed that they were completely unaware of the potential value of lode deposits of gold and other minerals. Most of the information avallable today about mineral occurrences of various kinds in the region was obtained by the earlyday prospectors and miners. In the areas where placer mining was carried on, the placer concentrates provided clues to the nature of mineralization in the head-waters of the streams being mined. All the placer-mining districts were visited by geologists of the U.S.Geological Survey, and they would have been able to identify any minerals present in the concentrates, if the miners themselves could not identify them.

The prospecting that has been done probably has been sufficient to rule out the likelihood that large deposits containing obviously valuable amounts of the common metals crop out in the region. Except where recent landslides or caving banks have exposed fresh rock, probably all the outcrops have been seen. Some may not have been examined carefully. If any minable deposits are yet to be found in outcrops, they most likely are deposits of such nature as to have escaped the attention of the traveler who, although perhaps not an experienced lode prospector, had some knowledge of minerals from working in placers. The part of the region that is below timberline is almost completely covered by soil and vegetation, and much of the part above timberline is also covered. Most of whatever remains to be discovered must be well hidden.

In the past few decades, new methods of geochemical and geophysical prospecting have been developed that can help the prospector to find deposits that are hidden under soil and vegetation. The supplies and equipment for some of these methods are moderate in cost and can be afforded by the independent prospector. Courses in geochemical and geophysical prospecting are offered for prospectors at the University of Alaska.

Some geophysical methods of exploration require equipment that can be afforded only by well financed companies. Exploration by these methods frequently begins with a study of all available information on the area to be explored, followed by aerial surveys with several kinds of airborne geophysical equipment. From the results of the aerial surveys, areas are selected for geophysical and geochemical surveys on the ground, and from the ground surveys sites are selected for additional work, such as drilling and trenching. These methods have not yet been applied to the YukonTanana region to any appreciable degree. During the past ten years several mining companies have shown interest in the region, but their work for the most part has been limited to the examination of known prospects found by independent prospectors. Probably each of the known deposits in the region that appears to have any promise has been examined by at least one mining company.

In 1964 the Division of Mines and Minerals began a program of geochemical investigations in Alaska. These investigations have consisted of collecting samples of stream sediments and having the samples analyzed for trace amounts of metals. Areas in which the stream sediments carry higher-than-normal amounts of metal are considered to be favorable areas in which to prospect. Results of the investigations in the Yukon-Tanana region have been published in the following Geochemical Reports, which are sold at offices of the Division for one dollar per copy:

No. 3: A Geochemical Investigation in the Richardson Area, Alaska;

No. 5: A Geochemical Investigation between Chatanika and Circle Hot Springs, Alaska;

No. 9: A Geochemical Investigation along the Taylor Highway, East-Central Alaska; 
No. 10: A Geochemical Investigation of the Nenana Highway Area, Alaska;

No. 11: A Geochemical Investigation of Stream Sediments in the Ellintt Highway Area, Alaska; and

No. 12: A Geochemical Investigation of Minook Creek, Rampart District, Alaska.

Stream sediment surveys were made in 1966 on the upper Tolovana River, in the Porcupine Dome - Mastodon Dome area in the Circle district, in the Pedro Dome - Coffee Dome area in the Fairbanks district, and on Columia Creek in the Fortymile district. Reports of these investigations are now in preparation and will be available in 1967.

The geologic mapping that has been done has demonstrated that mineralization in the region has been closely related to the igneous rocks. Chromium, nickel, and copper have been found in mafic rocks. Tungsten has been found in calcareous rocks near the margins of porphyritic granites. Gold, silver-bearing galena, tin, cinnabar, and copper have been found in lodes in the areas in which small granitic intrusions have been mapped, and in placers in streams draining such areas. The most favorable granitic intrusions are those less than 3 or 4 miles in diameter. Many of these small intrusions are shown on published geologic maps of the region; probably many more are covered and have not been mapped, but their presence may be indicated by granitic float in streams and on hillsides.

Most of the mineral occurrences shown on the accompanying maps are in the Fairbanks district. The apparent preponderance of mineral deposits in that district may give a distorted impression of the true distribution of mineral deposits throughout the region. Most of the known deposits have been found where most of the lode prospecting has been done.

Part of the land in the Yukon-Tanana region has been withdrawn from mineral entry. Boundaries of the withdrawals and boundaries of patented land are shown on maps in the offices of the U.S. Bureau of Land Management. Unpatented mining claims ordinarily are not shown on the Bureau of Land Management plats, but verbal descriptions of unpatented claims are recordedin the recording offices of the region. These plats and records will help the prospector to determine what ground has been staked, but he must continually be on the lookout in the field for location notices, claim corners, discovery monuments, and claim lines. The U.S. Bureau of Land Management maintains an office in Fairbanks. Recording offices in the region are at Fairbanks, Rampart, and Manley Hot Springs.

of the land in the region that is open to mineral entry, some is federal public domain and some is state-selected land. Here again, the records of the U.S. Bureau of Land Management show the boundaries of land that has been selected or applied for by the State. State land, generally, is open to mineral entry under the state's "Mining Rights Regulations", copies of which may be obtained from the State Division of Lands; this Division maintains an office in Fairbanks. The laws and regulations that pertain to claim staking are summarized in Information Circular No. 1, PROPER CLAIM STAKING IN ALASKA, which is available at offices of the Division of Mines and Minerals.

\section{MINERAL OCCURRENCES}

At the end of the following tabulation of mineral occurrences is a list of the abbreviations used for the references cited and the corresponding full titles of those references. In the tabulation, page numbers are not given for unpublished reports of the Division of Mines and Minerals and the Territorial Department of Mines, because most of these reports are only a few pages long and pertain to only one prospect or occurrence. Where occurrences are closely spaced, a single map number may represent more than one occurrence. Dollar values marked by an asterisk (*) were taken from reports publisned before 1934, and, therefore, are based on $\$ 20.67$ per ounce for gold rather than the present price of $\$ 35$ per ounce. 
Tanana quadrangle, Manley Hot Springs district.

American $\mathrm{Cr}$., trib. to Fish Lake.

Tanana quadrangle, Manley North side of Deep $\mathrm{Cr}$., trib. to Woodchopper $\mathrm{Cr}$.

Tanana quadrangle, Manley Hot Springs district.

Innesvale Gulch, trib. to Deep $\mathrm{Cr}$.

Tanana quadrangle, Manley Hot Springs district.

East bench of Sullivan $\mathrm{Cr}$.

trib. to Patterson $\mathrm{Cr}$.

Tanana quadrangle, Manley Hot Springs district.

Cache Cr., trib. to

Patterson $\mathrm{Cr}$.

Tof ty tin belt

Tanana quadrangle, Manley Hot Springs district.

Chromium in placer concentrate

B. $8440 ; 214$

Cassiterite in placer concentrate.

B. $8440 ; 238$. TDM 1: 34 .

\section{Cassiterite in placer concentrate}

\section{Cassiterite abundant in placer} concentrate.

\section{Native copper in placer con- centrate}

Cassiterite in placer concentrate. Hot Springs district.

From Woodchopper $\mathrm{Cr}$. to

$\mathrm{Ki}$ l larney $\mathrm{Cr}$.
Large amounts recovered in gold mining. B.844D; 211

Some production as a byproduct of gold mining. B.844D; 210, 239. TDM 1; 34 .

B. $8440 ; 210,239$.

B. $8440 ; 212$
125 long tons produced. Reserves in tailing piles 733,000 pounds in 1,259,000 $\mathrm{cu}$ yds.

R.1.5373; 7, 8, 55 . 
Tanana quadrangle, Manley Hot Springs district. On the summit of Hot Springs Dome

Tanana quadrangle, Manley Hot Springs district.

Omega $\mathrm{Cr}$. at the mouth of Chicago $\mathrm{Cr}$.

Tanana quadrangle, Manley Hot Springs district. On Shirley Bar between Rhode IsI and and Eureka Crs.

Tanana quadrangle, Manley Hot Springs district. On McCaskey Bar between

Pioneer and Kentucky Crs.

Tanana quadrangle, Manley Hot Springs district. On Pioneer Cr., trib. to

Eureka $\mathrm{Cr}$.

On Seattle Bar between

Seattle Jr. Cr., and

Skookum $\mathrm{Cr}$., tribs to

Pioneer $\mathrm{Cr}$.

Tanana quadrangle, Rampart district. On the ridge between Granite $\mathrm{Cr}$. and upper Minook $\mathrm{Cr}$.
Lode 20 to $35 \mathrm{ft}$ wide with complex sulfide mineralization. Copper, lead and cobalt present.

Forty-ft shaft and short ad Sampling indicates $\$ 1 *$ to $\$$ per ton of gold and 5 to 8 of silver.

B8440; 215-216

Scheelite in placer concentrate. Cinnabar in placer concentrate.

B844D; 204, 235 B844D; 204

Cinnabar in placer concentrate. Galena in placer concentrate.

B8440; 199, 202

B. $8440 ; 202$

iinnabar in placer concentrate.

B8440; 199.

Scheelite in placer concentrate. Cinnabar in placer concentrate.

TDMI ; 39.

B. $8440 ; 197$.

Scheelite in placer concentrate.

B. $8440 ; 197$.

Stibnite float found by U.S. Geological Survey party.
B8440; 217. 
Gill prospect.

Tanana quadrangle, Manley Hot Springs district.

Location indefinite, near

Pioneer and Eureka Crs.

Tanana quadrangle,

Rampart district. On

Ruby $\mathrm{Cr}$., trib. to

Minook $\mathrm{Cr}$.

Tanana quadrangle, Rampart district. On Hoosier Cr., trib. to Minook $\mathrm{Cr}$.

Tanana quadrangle, Rampart district. On Little Minook Cr., trib. to Minook $\mathrm{Cr}$.

Little Minook Jr. Cr., trib. to Minook $\mathrm{Cr}$.

Livengood quadrangle, Rampart district. On Hunter $\mathrm{Cr}$. above the mouth of Dawson $\mathrm{Cr}$.

On Hunter Creek opposite the mouth of Dawson $\mathrm{Cr}$.

Livengood quadrangle, Rampart district. On Quail Cr., trib. to Troublesome $\mathrm{Cr}$.
Silver-bearing galena float.

Bismuth in placer concentrate.

Scheelite, cinnabar, and native copper in placer concentrate.

Scheelite, cinnabar (?), native copper, chromium, and galena in placer concentrate.

Galena in placer concentrate.

Cassiterite in placer concentrate.

Galena and native copper in placer concentrate.

Mineralized dikes cutting sedimentary rock.

Cassiterite common in placer concentrate.
Two assays reported at 100 oz per ton of silver and $70 \%$ lead.

B. $8440 ; 217$.

Geochem Rept 12; 5 .

B. $8440 ; 187,197,234$.

B. $8440 ; 182-183,232-234$.

B. $8440 ; 185,234$.

B. $8440 ; 180$.

B. $8440 ; 180,232$.

One assay - 52 oz per ton of Silver.

B. $525 ; 146$.

TDM $1 ; 34$. 

Rampart district. Near the top of Sawtooth Mt.

Livengood quadrangle, Rampart district. On

Livengood quadrangle, Rampart district. On Gunnison $\mathrm{Cr}$., trib. to Troublesome $\mathrm{Cr}$.

Livengood quadrangle, Rampart district. On Troublesome $\mathrm{Cr}$. below the mouth of Union $\mathrm{Cr}$.

Livengood quadrangle, Tolovana district.

Livengood $\mathrm{Cr}$.

Livengood $\mathrm{Cr}$. and $\mathrm{its}$ tribs.

Livengood quadrangle,
Lens of stibnite discovered in 1942. Troublesome $\mathrm{Cr}$. Tolovana district. On Lillian $\mathrm{Cr}$., trib. to Livengood $\mathrm{Cr}$.

On Ruth Cr., trib. to Livengood $\mathrm{Cr}$.

On Olive Cr., trib. to Tolovana River.

On Olive, Ruth, and Lillian Crs. placer concentrate.

Galena in placer concentrate.

Cassiterite rare in placer concentrate.

Chromium in placers, probably derived from ultramafic rocks. 80-ft shaft; about 500 tons mined.

TDM 1958. TDM 2; 16.

Cassiterite and scheelite in B.844D; 192, 235, 236.

Scheelite in placer concentrate.

B. $844 D ; 235$.

Cinnabar in placer concentrate.

B. $8440 ; 192$.

B. $8440 ; 236$.

Scheelite in placer concentrate.

B.662; $270-271$. B. $712 ; 183$.

Scheelite in placer concentrate. B. $712 ; 183$.

Scheelite in placer concentrate. B. $712 ; 183$. TDM 1; 39.

Cinnabar in placer concentrates. TDM $1 ; 39$.

TDM 1; 34, 39.

C. $335 ; 3$. TDM 1; 17, 18. 
On Ruth $\mathrm{Cr}$.

North side of Lillian $\mathrm{Cr}$.

On the ridge east of Livengood $\mathrm{Cr}$.

At the heads of Ruth, Lillian, and Olive Crs.

At the heads of Ruth, Lillian, and Olive Crs.

Hudson cinnabar prospect.

Griffin prospect.

On upper Olive $\mathrm{Cr}$.

At the head of Lillian $\mathrm{Cr}$.

Livengood quadrangle, Tolovana district. On Lucky (or Goodluck) Cr., trib. to Livengood $\mathrm{Cr}$.

At the head of Livengood Cr.

Circle quadrangle, Fairbanks district. On Nome Cr., , trib. to Beaver $\mathrm{Cr}$.
Stibnite in place in bottom of placer cut.

Stibnite and cinnabar in thin seams exposed in cut bank.

Nickel in rock specimens from ridge and from Gertrude $\mathrm{Cr}$.

Numerous quartz veinlets up to 3 inches wide, carrying pyrite. arsenopyrite, and gold.

Chromite exposed in a small excavation.

Cinnabar in small amounts in narrow veinlets.

Quartz vein.

Cassiterite in placer concentrate.

Stibnite in place on placer bench claim.

Cassiterite in placer concentrate.
Covered by tailing.

B.662; 271. TDM 2; 16 .

TDM $1 ; 14$.

B. $712 ; 183$.

Reported to carry up to $\$ 1:$ per ton in gold and $\$ 2$ per ton in silver (1916 price. B. 662; 273-274.

B. $662 ; 274$.

TDM 1; 26.

Shaft and adit of unknown length. Two grab samples. 0.14 and 0.74 oz of gold pe ton, also traces of nickel. TDM 1955.

c. $335 ; 3$.

B. $712 ; 183$.

C. $331 ; 8$. TDM 1; 32 . 

prospect.
Circle quadrangle, Fairbanks district. On Dempsey Pup, trib. to Sourdough $\mathrm{Cr}$.

Circle quadrangle, Fairbanks district. Sourdough Cr., trib. to Chatanika River.

Circle quadrangle, Fairbanks district. At the heads of Sourdough and American Crs.

Circle quadrangle, Fai rbanks district. On Hope Cr., trib. to Faith $\mathrm{Cr}$.

Circle quadrangle, Circle district. On Eagle $\mathrm{Cr}$.

Circle quadrangle, Circle district. At the head of Dome $\mathrm{Cr}$. West of Porcupine Dome.

Circle quadrangle, Circle district. On Porcupine $\mathrm{Cr}$. trib. to Crooked $\mathrm{Cr}$.

Circle quadrangle, Circle district. On Mastodon Cr., trib. to Mammoth $\mathrm{Cr}$.
Lenses of stibnite up to $1 \mathrm{ft}$.

TDM 2; 11.
TDM 1; 32 .

Cassiterite scarce in placer concentrate.

Stibnite in heavy mineral fractions from granitic rocks.

Stibnite deposit reported uncovered in 1926 in digging a bedrock drain for placer mining.

Gold-quartz vein $4 \mathrm{ft}$ wide reported to have been uncovered in placer mining and later covered again.

Gold lode.

Cassiterite in placer concentrate.

Cassiterite in small amounts in placer concentrate.
C. $348 ; 10-11$.

Covered by tailing. TDM 2; 12 .

B. $314 ; 189-190$.

Undeveloped prospect. B. 897C; 225-226.

B. $897 C ; 226$.

TDM $1 ; 32$. 
Circle quadrangle, Circle district. North Fork of Harrison $\mathrm{Cr} .3 / 4 \mathrm{mile}$ above its junction with the South Fork.

Circle quadrangle, Circle district. On the North Fork of Harrison $\mathrm{Cr}$.

Circle quadrangle, Circle district. On upper Deadwood $\mathrm{Cr}$.

On upper Deadwood $\mathrm{Cr}$.

Circle quadrangle, Circle district. On the west

side of Deadwood $\mathrm{Cr}$. near Discovery Gulch.

Circle quadrangle, Circle district. On Deadwood $\mathrm{Cr}$.

Discovery placer claim on Deadwood $\mathrm{Cr}$.

On Deadwood $\mathrm{Cr} .1 / 2 \mathrm{mile}$ below the mouth of Switch $\mathrm{Cr}$.

On Deadwood $\mathrm{Cr}$.

Circle quadrangle, Circle district. Miller HouseCircle Hot Springs area.
B. $314 ; 189-190$.

Cassiterite in small amounts in placer concentrate.

TOM 1; 32 .

Mineralized fracture zone 8 inches wide with pyrite and galena. Schist country rock.

Reported to carry $\$ 6 *$ per ton in gold and $\$ 8$ in silver

(1907 price).

B. $314 ; 189-190$.

Galena with pyrite in mineralized fracture zones.

B. 897C; 237.

Small vein of wolframite reported

B. 897 C 237.
Cassiterite and wolframite in placer C.335; 5. 8.897C; 237. concentrate.

Wolframite, cassiterite, and scheelite in placer concentrate.

Heavy-mineral fraction of granite contained $10 \%$ galena.

Galena in placer concentrate.

Cassiterite, wolframite, and scheelite in veins and placer concentrates.
TDM 1; 32, 37.

Principal site of mineralization believed to be south of Discovery Gulch. TDM 1; 41 .

C. $348 ; 13$.

B. $824 ; 162$.

C. $348 ; 11-13$ 
Circle quadrangle, Circle district. On Switch $\mathrm{Cr}$., trib. to Deadwood $\mathrm{Cr}$.

Circle quadrangle, Circle district. On Hot Springs and Ketchem Crs.

Circle quadrangle, Circle district. On Portage $\mathrm{Cr}$., trib. to Medicine Lake.

Circle quadrangle, Circle district. On Half Dollar Cr., trib. to Bottom Dollar Cr., trib. to Birch Cr.

Circle quadrangle, Fairbanks district. On Palmer $\mathrm{Cr}$., trib. to Chena River.

Big Delta quadrangle, Fairbanks district. On Pine Cr., trib. to Beaver Cr., trib. to South Fork of Chena River.

Big Delta quadrangle, Fairbanks district. On Caribou Cr., trib. to Salcha River.

On No Grub and Caribou Crs.
Cassiterite in small amounts in placer concentrate.

Scheelite in placer concentrate.

Cassiterite in placer concentrate. Traces of chalcopyrite in placer concentrate.

Cassiterite abundant in placer concentrate.

C. $335 ; 5$. TDM 1; 32 .

Scheelite abundant in placer concentrate.

Cassiterite scarce in placer concentrate.

Cassiterite and scheelite in small amounts in placer concentrate.

Bismuth and bismuthinite reported in veins. c. $335 ; 5$.

TDM 2; 19.

TDM 1; 34.

TDM 1; 37.

c. $335 ; 5$.

TDM 1; 39.

TDM 1; 34.39.

MWRA; 98. 
Big Delta quadrangle, Fairbanks district.

Northeast of "The Splits"

in the Salcha River.

Ricks nickel prospect.

Democrat lode

Blue lead.

Big Delta quadrangle, Fairbanks district. At the head of Ricks $\mathrm{Cr}$., trib. to North Fork of Salcha River.

Big Delta quadrangle, Fairbanks district. Location indefinite.

Big Delta quadrangle, Richardson district. North side of Democrat $\mathrm{Cr}$., trib to Banner $\mathrm{Cr}$.

Big Delta quadrangle, Richardson district. On Buckeye $\mathrm{Cr}$., trib. to Banner $\mathrm{Cr}$.

Big Delta quadrangle, Richardson district. On Tenderfoot $\mathrm{Cr}$., trib. to Tanana River.

Big Delta quadrangle,
Chromium in dunite or peridotite. Goodpaster district. At the head of Summit Cr. , trib. to Boulder Cr.

Nickel in dolomite.

Considerable areas of serpentine contain up to $0.6 \%$ nickel, traces of platinum, and small amounts of chromium.

Gold lode in rhyolite.

Galena, scheelite, and probably placer mining. Jamesonite and a small amount of pyrite. Schist country rock with granitic intrusions.
Mostly less than $1 \%$ chromium. TDM $1 ; 16$.

TOM. 1954 B.

Adit of unknown length driven prior to 1921 .

B.739; 33 .

Geochem Report 3; 2. cassiterite in placer concentrate.

c. $331 ; 13$.

Gold-bearing galena float found in

Gold-quartz vein $21 / 2 \mathrm{ft}$ wide with
More than 100 tons mined and milled in 1938. More than $700 \mathrm{ft}$ of underground workings on the Blue lead and Blue lead extension.

B.917A; 30. TDM 1937. TDM; 1938A. TDM 1941. 
Grizzly Bear lead.

Gray lead.

Johnson prospect.
Big Delta quadrangle, Goodpaster district. At the head of Johnson $\mathrm{Cr}$. trib. to Tibbs $\mathrm{Cr}$.

Big Delta quadrangle, Goodpaster district. At the head of Tibbs $\mathrm{Cr}$., west of Black Mountain.

At the head of Tibbs $\mathrm{Cr}$.

Big Delta quadrangle, Goodpaster district. At the head of Boulder $\mathrm{Cr}$., trib. to South Fork of Goodpaster River.

Big Delta quadrangle, Goodpaster district. At the heads of Healy, Volkmar, and South Fork of Goodpaster Rivers.

Eagle quadrangle, Goodpaster Molybdenite float. district. At the head of the South Fork of Goodpaster River. Location indefinite.

Eagle quadrangle,

Goodpaster district. On the granite. the south side of Mt. Harper at the head of Goodpaster River.

My Creek prospect

Eagle quadrangle, Fortymile district. On My Cr., trib. to Molly Cr., trib. to

Middle Fork of Fortymile R.
Gold-quartz vein $11 / 2$ to $2 \mathrm{ft}$ wide. Similar to the Blue lead.

Gold-quartz vein $2 \mathrm{ft}$ wide. Similar to the Blue lead.

Jamesonite in gold-quartz veins.

Molybdenite in small quartz veins in granite.

Gold-quartz veins.

Undeve loped prospects. TDM 1938A.

TDM 1938 A.

Reported to be 3 claims long B.692; 329. B.926C; 194.

R.1.4173;28-29. TDM 2; 15. TDM 1942 
Mitchell copper prospect.

Hajdukovich molybdenum prospect.
Fortymile district. On My Cr., trib. to Molly $\mathrm{Cr}$.

In the My $\mathrm{Cr}$. drainage I $1 / 2$ miles south of the Ruby Silver claim.

Eagle quadrangle, Fortymile district. In the headwaters of Our $\mathrm{Cr}$, trib. to Molly $\mathrm{Cr}$.

Tanacross quadrangle. Vicinity of Tetlin location indefinite.

Eagle quadrangle, Fortymile district. On Ketchumstuk Cr., trib. to Mosqui to Fork.

Eagle quadrangle, Fortymile district. On upper Ketchumstuk $\mathrm{Cr}$.

Eagle quadrangle, Fortymile district. On Mt. Veta.

Eagle quadrangle, Fortymile district. In the Middle Fork drainage 8 miles from the head of Ketchums tuk $\mathrm{Cr}$. Location indefinite.
Silver-bearing galena in a calcite vein.

Undeveloped prospect. DMEM 1962B. C. $335 ; 18$.

Silver-bearing galena in a calcite vein with a small amount of copper.

Undeveloped prospect. DMEM $1962 B$.

Silver reported in a $15-\mathrm{ft}$ wide band of magnetite

Undeveloped prospect. DMEM 1962B.

High-grade specimens of molybdenum obtained.

Narrow, copper-bearing vein in schist.

Stibnite prospect.

Stibnite deposit reported in 1935.

Scattered copper float.
B880A; 87.

B. $542 ; 214$.

Open pits only. B. $520 ; 213$. B.542; 214 . DMEM $1962 C$.

Ann. Rept. 1962; 85-88.

B. $872 ; 245$. TDM 1; 13. 
Eagle quadrangle, Fortymile district. On the Middle Fork of Fortymile River 12 miles below Joseph village.

Eagle quadrangle, Fortymile district. At the mouth of Gold $\mathrm{Cr}$., trib. to Mosquito Fork.

Eagle quadrangle, Fortymile district. On Lilliwig Cr., trib. to Ingle $\mathrm{Cr}$.

Eagle quadrangle, Fortymile district. At the head of Myers Fork, trib. to Chicken $\mathrm{Cr}$.

Eagle quadrangle, Fortymile district. On Forty-five Pup. trib. to Buckskin $\mathrm{Cr}$.

Eagle quadrangle, Fortymile district. On Buckskin Cr., trib. to South Fork of Fortymile River.

Eagle quadrangle, Fortymile district. On Franklin Cr., trib. to South Fork of Fortymile River.
Discovery of stibnite reported in 1917.

Gold-quartz veins and stringers in greenstone.

Lode 40 to $50 \mathrm{ft}$ wide consisting of quartz with pyrite and chalcopyrite in sericitized diorite.

Narrow veinlet of quartz and calcite carrying gold. Schist wall rock.

Scheelite abundant in placer concentrate.

Cassiterite in placer concenerate. TDM 2; 19.
Adit 40-ft long. An unsuccessful attempt was made in 1911 to recover the gold in a crude arrastre powered by a waterwheel.

B. $520 ; 213$.

Sulfides from the lode assayed $1.87 \mathrm{oz}$. of gold $2.05 \mathrm{oz}$ of silver, and 0.76 copper. B.813; 141 .

Small production from handdug open pits. DMEM 1960 A.

TDM 2; 28. 
Eagle quadrangle, Fortymile district. On

Stonehouse $\mathrm{Cr}$., trib. to

Chicken $\mathrm{Cr}$.

LaFlamme copper prospect.

Fortymile district. On

Chicken $\mathrm{Cr}$., trib. to

Mosquito Fork.

On a small, un-named

Eagle quadrangle,

Fortymile district. On

Slide Cr., trib. to

Mosquito Fork near

Chicken.

Eagle quadrangle, Fortymile district. At of Fortymile River.

Eagle quadrangle, Fortymile district. On Napoleon Cr., trib. to

Eagle quadrangle,

Fortymile district. On Wade $\mathrm{Cr}$., trib. to Walker Fork.

Eagle quadrangle,
B. $813 ; 138$.

Eagle quadrangle Stibnite lode. stream west of Chicken $\mathrm{Cr}$. Atwater Bar on South Fork

South Fork of Fortymile R. Fortymile district. At "The Kink" on the North Fork of Fortymile River. some copper.

Cinnabar in placer concentrate.

B.897C; 183.

Cinnabar and cassiterite in placer concentrate.

Cassiterite in placer concentrate.
Development work reported in 1920.

B. $722 ; 24$.

C. $335 ; 21$.

Montmorillonite-type clay carries traces of goethite, covellite, and chalcopyrite.

Narrow, low-grade vein carrying

Exposed in road cut. TDM $1957 E$.

\section{Cassiterite and scheelite in}

C. $335 ; 11$.

B.897C; 166. TDM 1; 27,32 . 
Weston prospect. prospect.
Eagle quadrangle,

Fortymile district. On the Fortymile River below the mouth of $0^{\prime} \mathrm{Brien} \mathrm{Cr}$.

Eagle quadrangle, Fortymile district. On Dome $\mathrm{Cr}$., trib. to O'Brien $\mathrm{Cr}$.

Eagle quadrangle,

Fortymile district. On Fourth of July Cr., trib. to Slate $\mathrm{Cr}$., trib. to North Fork of Fortymile R.

Eagle quadrangle, Eagle district. On Copper Cr. , trib. to Charley River.

Eagle quadrangle, Eagle district. On Flume $\mathrm{Cr}$., trib. to Seventymile R.

Eagle quadrangle, Eagle district. On Canyon $\mathrm{Cr}$., trib. to Seventymile R.

Eagle quadrangle, Eagle district. On Fox Cr., trib. to Seventymile R.

On Lucky Gulch, trib. to Fox $\mathrm{Cr}$.

Jenkins prospect. Eagle quadrangle, Eagle district. On Eagle Bluff near the town of Eagle.
Veinlets carrying scheelite uncovered in placer cut.

Galena and cinnabar in placer concentrate.

Large pieces of galena float

found in gravel

C. $335 ; 19$.

B.897C; 190 .

Lode carrying copper, lead, gold, silver and tungsten.

Wide, low-grade mineralized zone carrying gold, pyrite, and arsenopyrite.

Cinnabar in placers.

Cassiterite scarce in placer concentrate.

Small amount of platinum in placers. TDM $1 ; 20$.

Copper, nickel, and cobalt minerals in ultramafic rocks.
B. $872 ; 245$. TDM 1; 27. TDM 19568 .

TDM 1; 32.

114-ft adit. C. $335 ; 7$. TDM 1956B. Ann. Rept. 1961; 64-65.

Adit $60 \mathrm{ft}$ long. TDM 1956A.

C. $316 ; 3$. TDM 1953. 
Social Security.

Ready Bullion groupincludes properties sometimes called the Hudson Mine and Eva Quartz Mining Co.
Charley River quadrangle, Eagle district. On Fourth of July Creek, trib. to Yukon River.

Fairbanks quadrangle, Fairbanks district. On the north side of Emma Cr., trib. to Cripple $\mathrm{Cr}$.

Fairbanks quadrangle, Fairbanks district. On the south side of Ester $\mathrm{Cr}$., one mile southwest of the Ready Bullion mine.

Fairbanks quadrangle, Fairbanks district. On Cripple Cr., trib. to Chena River.

Fairbanks quadrangle, Fairbanks district. On Ester Cr., trib. to Cripple $\mathrm{Cr}$.

Fairbanks quadrangle, Fairbanks district. North of Ester $\mathrm{Cr}$. east of Willow $\mathrm{Cr}$.

Fairbanks quadrangle, Fairbanks district. At the head of Ready Bullion $\mathrm{Cr}$., trib. to Ester $\mathrm{Cr}$.
Large pieces of galena reported in gravel.

Gold-quartz vein about 10 inches wide.

Gold prospect.

Cassiterite and scheelite in placer concentrate.

Cassiterite and scheelite in placer concentrate.

Quartz vein carrying stibnite and arsenopyrite, reported to be 12

to $14 \mathrm{ft}$ wide. Schist wall rock.

Several gold-quartz veins. c. $335 ; 19$.

$225 \mathrm{ft}$ of underground workings. 30 tons reporte to have milled $\$ 17$ to $\$ 18$ per ton. TDM 1938B.

Shaft $85 \mathrm{ft}$ deep and $90 \mathrm{ft}$ of other underground workings. TDM 1938B.

TDM 1; 32, 39.

TDM 1; 32, 39.

90-ft shaft. B. $8498 ; 123$.

Vein system is about $5000 \mathrm{f}$ long. About $2000 \mathrm{ft}$ of unde ground workings. Productive from 1926 to 1932 . $18 \mathrm{clai}$ in the group.

B.525; 203-206. B.592; 350 352. B.8498; 123-127. 
Ready Bullion group

Silver Dollar groupalso called the Makaich or Radovich group.

M'Queen property. (cont.)
Cotton Blossom claim.

Fairbanks quadrangle, Fairbanks district. On the west side of Ready Bullion $\mathrm{Cr}$. I $1 / 2$ miles north of Ester $\mathrm{Cr}$.

Fairbanks quadrangle, Fairbanks district. On the west side of Ready Bullion $\mathrm{Cr}$., trib. to Ester $\mathrm{Cr}$.

Fairbanks quadrangle, Fairbanks district. On the ridge west of Ready Bullion $\mathrm{Cr}$.

Fairbanks quadrangle, Fairbanks district. On the $\mathrm{ridge} 1 / 4 \mathrm{mile}$ west of Ester Dome. pect. (not to be confused with the

Fairbanks quadrangle, Fairbanks district. At the head of Ready Bullion

$\mathrm{Cr}$.

Ready Bullion group).
Ready Bullion pros-
Stibnite present in some of the veins.

5-ft-wide vein of quartz and altered schist. Schist country rock.

Stibnite in bunches and scattered sparingly through quartz stringers.

Quartz with gold and sulfides.

Stibnite lode.

2 shafts, one probably deeper than $75 \mathrm{ft}$. B. 849 B; 123.

Production of 100 tons reported during 1916 to 1918. B. $8498 ; 157$.

Gold prospect. No definite vein. Schist country rock.

8.849B; 127. TDM 1951

2 adits, several hundred feet of workings. Some ore milled; said to have been low-grade.

MIMI 1933; 142-143.

B. $525 ; 209$.
MIMI 1933; 141-142.

TDM 1938B. TDM 1951

TDM 1957B. ARMI 1922; 109.

$U$ of A 1931; 45.

B. $8498 ; 127-128$. TDM 19388 .
Several hundred tons of high-grade ore mined from vein segments and bunches of quartz. About $2700 \mathrm{ft}$ of underground workings. TDM 1938 B. 

mine.

Farmer.

Vuyovich prospect.

Stay

Little Eva.
Fairbanks quadrangle, Fairbanks district. On the west fork of Nugget Cr., trib. to Goldstream Cr.

Fairbanks quadrangle, Fairbanks district. At the head of the west fork of Ready Bullion $\mathrm{Cr}$.

Fairbanks quadrangle, Fairbanks district. On the north side of Ester $\mathrm{Cr}$. below the mouth of Ready Bullion $\mathrm{Cr}$.

Fairbanks quadrangle, Fairbanks district. East of lower Eva Cr., trib. to Ester $\mathrm{Cr}$.

Claims apparently were included in the Stay.

Claims apparently were included in the Bluebird (109).

Fai rbanks quadrangle, Fairbanks district. On the west side of Eva Cr., trib. to Ester $\mathrm{Cr}$.
Gold lode of quartz and silicified schist. Schist country rock.

4-ft-wide lode of gold-quartz and brecciated wall rock.

Country rock is schist.

At least 3 gold-quartz veins ranging in width from 2 inches to 4 feet.

Stibnite and arsenopyrite in lenses in quartz.

Gold-quartz vein 6 to 18 inches wide.

Gold-quartz vein $1 / 2$ to $2 \mathrm{ft}$ wide.

Narrow gold-quartz vein and numerous flat-lying lenses.

Gold-quartz vein $3 \mathrm{ft}$ wide. 20-ft-wide lode. Several open pits and 3 adits. Small amount of ore reported to have averaged $\$ 20$ per ton. B. 849B; 120-122.

2 adits of unknown length. Small production. One sampl $\$ 7.06 *$ per ton.

B.592; 352. B849B; 122-123. TDM 1938 .

4 adits totalling about 400 $\mathrm{ft}$ and several open pits. Small production. B662; 409. B.8498; 128. TDM 1954A. TDM 1957A. DMEM $1963 B$.

B. $8498 ; 128$.

Several shafts, winzes, and adits. 700 tons of ore milled $\$ 16,000$ ᄎ. B. 849B; 129-133. $U$ of $A 1931 ; 28-30$.

35-ft shaft and 30-ft drift. MIMI 1933; 138. TDM 1938B.

Adit driven in 1912. B. 525; 206-208.

Shafts, drift, and winze totalling $200 \mathrm{ft}$. TOM 1938 B. 
Bluebird - also known as the McDonald.

Combination claim $\varepsilon$ Combination shaft.

Little Flower.

Billy Sunday.

Ryan lode.

Mohawk mine. in the Bluebird.

Fairbanks quadrangle, Fairbanks district. On the east side of Eva $\mathrm{Cr}$., trib. to Ester $\mathrm{Cr}$.

Fairbanks quadrangle, Fairbanks district. On the east side of upper Eva Cr., trib. to Ester $\mathrm{Cr}$.

Fairbanks quadrangle, Fairbanks district. At the head of the south fork of St. Patrick $\mathrm{Cr}$.

Fairbanks quadrangle, Fairbanks district. On St. Patrick $\mathrm{Cr}$. east of Ester Dome.

Fairbanks quadrangle, Fairbanks district. On St. Patrick $\mathrm{Cr}$. below the Ryan lode.
Gold-quartz vein from a fraction of an inch to $4 \mathrm{ft}$ wide.

Stibnite and arsenopyrite in boulders on the dump at the shaft.

Gold-quartz vein $2 \mathrm{ft}$ wide.

Gold-bearing vein of crushed quartz with some schist, 12 to 14 inches wide. Schist wall rock.

Stibnite and arsenopyrite in the Billy Sunday vein.

Gold lode 40 to $70 \mathrm{ft}$ wide with most of the mineralization in a band 9 to $20 \mathrm{ft}$ wide. Schist wall rock.

Stibnite and arsenopyrite in the Ryan lode.

Gold-quartz vein 9 inches to $6 \mathrm{ft}$ wide, averaging $3 \mathrm{ft}$. Schist wall rock.
Shaft and other workings.

240 tons milled $\$ 19^{*}$ per tc 8.8498; 133-135.

MIMI 1933; 138-140.

$U$ of $A 1931 ; 30-32$.

TDM 1938B.

B. 8498; 134-135.

450- $\mathrm{ft}$ adit and 50- $\mathrm{ft}$ winze 680 tons reported to have milled $\$ 25$ per ton. TDM 1938B.

$120-\mathrm{ft}$ shaft and other workings. 1900 tons mille $\$ 26 *$ per ton.

B.8498; 139-142. ARMI 1922; 106-107.

B. $849 B ; 142$.

Several shafts and rather extensive underground workings.

B. $525 ; 209$. B. $662 ; 413$ B. 8498 ; $135-138$. TDM $1938 \mathrm{E}$ ARMI 1922; 106-107.

B. $8498 ; 136$.

$2900 \mathrm{ft}$ of drifts and more than $1800 \mathrm{ft}$ of raises and winzes. Production reporte at more than $\$ 200,000 *$. $\$ 2$ per ton average. 
Mohawk mine

(Cont.)

Bondholder group also known as the Tyndall and Finn property.

Fair Chance

Wandering Jew.

Clipper.

117 St. Paul.
Claims have been included in the Mohawk mine.

Fairbanks quadrangle, Fairbanks district. On St. Patrick $\mathrm{Cr}$. near the Ryan lode.

Fairbanks quadrangle, Fairbanks district. Between St. Patrick and Eva Crs.

Fairbanks quadrangle, Fairbanks district. On the east fork of Eva Cr., trib. to Ester $\mathrm{Cr}$.

Fairbanks quadrangle, Fairbanks district. On the west fork of Eva $\mathrm{Cr}$. southeast of Ester Dome.
Stibnite present in the vein at the Mohawk mine but is scarce and erratic.

Mineralized zone consisting of gouge, schist, and quartz, carrying gold. Schist wall rock.

Gold-quartz vein 4 to 18 inches wide with sulfides.

Vein 1 to 8 inches wide carrying sulfides and free gold. Schist Wall rock.

Gold-quartz vein 3 to $4 \mathrm{ft}$ wide. Schist wall rock.

Stibnite and arsenopyrite in the vein.
B. $8498 ; 147-148 . \quad$ B $783 ; 8$. $U$ of $A 1931 ; 41-42$ MIMI 1933; 145.

B. $8498 ; 145$. B. $783 ; 8$.

$U$ of A 1931; 40. B. $849 \mathrm{~B} ; 146$.

3 shafts. Grab sample $\$ 5.95^{\circ}$ per ton. Small production.

3. $8498 ; 139$.

50- $f t$ shaft and other workings. Small productio $\$ 10 \div$ to $\$ 20 \div$ per ton. B. 8498 ; 147. TDM 1938B. $U$ of $A 1931 ; 42-43$.

237-ft adit. Samples reported to have assayed about \$12* per ton. B. $849 \mathrm{~B} ; 152$. MIMI 1933; 14 TDM 1938 .

$300-\mathrm{ft}$ adit and other workings. 1000 tons of ore milled $\$ 30 *$ per ton. B. 849B; 128-129. ARMI 1922; 108-109. TDM 1938B.

B. $8498 ; 129$. 
Fairbanks quadrangle, Fairbanks district. At the head of St. Patrick $\mathrm{Cr}$.

Macomb.

Fairbanks quadrangle, Fairbanks district. At the head of Eva Cr. ,

trib. to Ester $\mathrm{Cr}$.

Fairbanks quadrangle, Fairbanks district. At the head of St. Patrick $\mathrm{Cr}_{r}$. west of the Prometheus.

Fairbanks quadrangle, Fairbanks district. At the head of St. Patrick $\mathrm{Cr}$. between the Wandering Jew and the top of Ester Dome.

Fairbanks quadrangle, the head of St. Patrick $\mathrm{Cr}$. northwest of the Mohawk.

Fai rbanks quadrangle, Fairbanks district. On the ridge north of $\mathrm{St}$. Patrick $\mathrm{Cr}$. between the Mohawk and Grant mines.

\section{Jamesonite and covellite present} in the vein.

Gold-quartz vein 6 inches to 4 feet wide, averaging 12 inches.

Gold-quartz vein with sulfides, $2 \mathrm{ft}$ wide.

Production of 100 tons reported during 1915 and 1916 ARMI 1922; 110-111.

Shallow shafts and open pit B. $8498 ; 148$.

60-ft shaft. One grab sampl assayed $\$ 9.52 *$ per ton. including $6.4 \mathrm{oz}$ of silver per ton.

B. $8498 ; 148$.

$U$ of A 1931; 39.

B.849B; 148.

$120-\mathrm{ft}$ shaft and other workings. $\$ 26,000 *$ producer from 520 tons of ore. B. 8498 ; $147-148$.

$U$ of $A 1931 ; 41-42$

MIMI 1933; 145.

60- $\mathrm{ft}$ shaft and other workings. 125 tons reported to have milled $\$ 30$ * per ton.

ARMI 1922; 108.

Gold-bearing vein of crushed schist, gouge, and quartz. B. $8498 ; 152$.
Two shafts 30 to $50 \mathrm{ft}$ dee 
$124 \quad$ Grant mine.

Fairbanks quadrangle, Fairbanks district. On the ridge north of St. Patrick $\mathrm{Cr}$.

125 Elmes.

Fairbanks quadrangle Fairbanks district. On Happy $\mathrm{Cr}$. east of Ester Dome.

\section{$126 \quad$ Cosgrove and} Krutsch.

127 Lincoln.

128. Royal Flush.

Fairbanks district. On the south side of Happy $\mathrm{Cr}$., trib. to Chena R.

Fairbanks quadrangle, the head of Happy $\mathrm{Cr}$. east of Ester Dome.

Fairbanks quadrangle, Fairbanks district. On the ridge between Happy and Sheep Crs.

Sanford. Also known Fairbanks quadrangle,
Gold-quartz vein 2 to $4 \mathrm{ft}$ wide.

Gold-quartz vein. Schist wall rock.

Large pieces of stibnite float found. Fairbanks district. At as the Lone Tree mine. Fairbanks district. On the summit of the ridge between Sheep and Happy crs.
Gold-quartz vein 9 inches wide.

Gold-quartz vein $3 \mathrm{ft}$ wide. Faulted a short distance down-dip from the surface.

Two gold-quartz veins; one 10 to 12 inches wide and one 4 to 12 inches wide.

240- $f t$ shaft and other workings. Several hundred tons reported to have milled $\$ 15^{*}$ to $\$ 20^{*}$.per ton.

B849B; 150. MIMI 1933; 144 . $U$ of $A$ 1931: $37-39$.

$U$ of $A$ 1951; 1-26.

100-ft shaft and other workings. One grab sample assayed $\$ 8.64 *$ per ton. Some production. B849B; 150. TDM 1938B.

TOM 1; 11.

37-ft shaft. Grab sample $\$ 160$ per ton.

TDM 1938B.

85- $\mathrm{ft}$ shaft. $300 \mathrm{ft}$ of drifts and cross-cuts. 208 tons averaged $\$ 47.50$ per ton. TOM 1938B.

105-ft shaft and a few hundred $\mathrm{ft}$ of drifts. 150 tons milled $\$ 6,700$.

$U$ of $A$ 1931; 43-45. B. $849 \mathrm{~B} ; 149$. MIMI 1933; 145. TDM 1938B. 
132. Grant.

$134 . \quad$ Lepsoe.
Fairbanks quadrangle, Fairbanks district. Head of Sheep $\mathrm{Cr}$. Northeast of Ester Dome.

Fairbanks quadrangle, Fairbanks district. On the ridge between Sheep and Nugget Crs.

Fairbanks quadrangle, Fairbanks district. On the divide between Sheep and Nugget Crs.

Fairbanks quadrangle Fairbanks district. At the head of the west fork of Sheep $\mathrm{Cr}$.

Fairbanks quadrangle, Fairbanks district. On the ridge east of Nugget Cr., 2 miles northwest of Ester Dome.

Livengood quadrangle, Fairbanks district. On Eagle Cr., trib. to Treasure $\mathrm{Cr}$.

Livengood quadrangle, Fairbanks district. On the east side of Eagle Cr., trib. to Treasure $\mathrm{Cr}$.
Gold-quartz vein with gouge. Vein is 2 to 12 inches wide. Wall rock is mica schist.

Gold-quartz vein with small amount of sulfides, 1 to 6 inches wide.

Gold-quartz vein 5 to 6 inches wide with small amounts of arsenopyrite and stibnite. Quartzite schist wall rock.

Quartz vein 18 inches wide at the surface; narrower in depth. Silver present in tetrahedrite; also stibnite and galena present.

20-ft wide gold-quartz vein. Granite porphyry dike parallels vein.

Stibnite lode with lenses up to $9 \mathrm{ft}$ wide reported.

Stibnite lenses 3 to 4 feet wide. Probably the extension of the Scrafford mineralized zone.
2 adits $-200 \mathrm{ft}$ and $150 \mathrm{ft}$ Some ore reported to have milled $\$ 10^{*}$ per ton. $8498 ; 149$.

70-ft shaft. Small tonnage reported to have milled mor than $\$ 80$ per ton.

MIMI 1933; 145.

60-ft shaft and some additional workings. Grab sample $\$ 9.22 *$ per ton. B849B; 122.

$130 \mathrm{ft}$ shaft.

B. $525 ; 197$. B.592; 353 .

Small amount of development B. $8498 ; 152$.

Production during World War I. Exploration work in 1964.

B.649; 17-41. B8498; 156-1 TDM $2 ; 10$.

90-ft shaft.

TDM $2 ; 10-11$ 
Fairbanks quadrangle, Fairbanks district. On the ridge north of $\mathrm{Big}$ Eldorado $\mathrm{Cr}$., 2 1/2 miles west of Elliott Highway.

Livengood quadrangle, Fairbanks district. On the west side of the ridge between Vault and Dome Crs.

Livengood quadrangle, Fairbanks district. On Vault $\mathrm{Cr}$., trib. to

Chatanika River.

\section{McGrath prospect.}

Fairbanks quadrangle, Fairbanks district. On the ridge south of Engineer $\mathrm{Cr}$.

141 Engineer.

Fairbanks quadrangle, Fairbanks district. On the point of the ridge one-eighth mile south of Engineer $\mathrm{Cr}$.

Fairbanks quadrangle,
Two prospects: a gold-quartz vein that averages 12 inches wide, and a 50-ft wide mineralized zone in schist.

Vein up to $31 / 2 \mathrm{ft}$ wide with fault zone along hanging wall. Arsenopyrite, pyrite, and stibnite present in addition to gold and silver. Wallrock is quartzite schist. A 7-ft-wide granitic dike is present.

Stibnite body; 38 to 42 percent antimony.

Gold-quartz vein 7 inches wide.

Two parallel gold-quartz veins Fairbanks district. On the ridge south of

Engineer $\mathrm{Cr}$. with arsenopyrite.

Gold-quartz vein 14 inches wide.
Adit $75 \mathrm{ft}$ vertically below the summit of the ridge cut the mineralized zone; grab sample \$0.23* per ton. Shaft $102 \mathrm{ft}$ deep on goldquartz vein; 8 tons reported to have milled 13 oz of gold; grab sample $\$ 24.07^{*}$ per ton.

B. 8498; 153-154.

One shaft $300 \mathrm{ft}$ deep; one shaft $100 \mathrm{ft}$ deep. Grab samples from dump assayed $\$ 1.46 *$ and $\$ 2.83 *$ per ton. No work done since 1912 . B. 525 ; 194-196. B. $542 ; 181$ 182. B8498; 80-81. ARMI 1922; 103.

TDM $1 ; 10$.

Grab sample from dump assayed \$2.86* per ton. B. $8498 ; 153$.

Grab sample from dump assayed $\$ 15.96 *$ per ton. B. $849 \mathrm{~B} ; 153$. 
Fairbanks quadrangle,

Fairbanks district. On

Gold-quartz float.

the knob between Goldstream and Engineer Crs.

Fairbanks quadrangle, Fairbanks district. Head of Columbia $\mathrm{Cr}$., trib. to Chena River.

Livengood quadrangle, Fairbanks district. On Goldstream Cr., trib. to Chatanika River.

Fairbanks quadrangle, Fairbanks district. On First Chance $\mathrm{Cr}$., trib. to Goldstream $\mathrm{Cr}$.

Fairbanks quadrangle, Fairbanks district. At the head of First Chance Cr., trib. to Goldstream $\mathrm{Cr}$.

Fairbanks quadrangle, Fairbanks district. At the head of Steele $\mathrm{Cr}$. near the Spruce Hen claim.

Fairbanks quadrangle, Fairbanks district. On Gilmore $\mathrm{Cr}$., trib. to Goldstream $\mathrm{Cr}$.

Fai rbanks quadrangle, Fairbanks district. At the head of Rose Cr., trib. to Gilmore $\mathrm{Cr}$.

Gold-quartz vein. concentrate. formation. veinlets.
Cassiterite scarce in placer

Cassiterite and scheelite in placer concentrate.

Scheelite with some molybdenite. A replacement deposit in limestone within the Birch Creek schist

Scheelite with some molybdenite.

Cassiterite and scheelite in placer concentrate.

Small amounts of stibnite in tiny 100-ft adit. Low-grade vei B. $525 ; 210$.

TDM 1; 32.

Found in hand-dug open pits B. $849 \mathrm{~B} ; 153$.

TOM 1; 32, 39, 41 .

60- ft shaft in 1956. B. $662 ; 421-424$. B. 10241 ; 201-206. B.925C; 196. R.I. 4174; 23-26. TDM 19570 .

Two adits, one $80 \mathrm{ft}$ long. B.692; 326-327.

TDM 1; 32, 39.

\section{B. $592 ; 346$.}


Fairbanks quadrangle, Fairbanks district. At the head of Rose $\mathrm{Cr}$., trib. to li ilnore $\mathrm{Cr}$..

Fairbanks quadrangle, Fairbanks district. On the ridae between Steele and $\operatorname{Rex} \mathrm{Cr}$., trib. to Smallwood $\mathrm{Cr}$.

Fairbanks quadrangle, Fairbanks district. At trib. to Smallwood $\mathrm{Cr}$.

Fairbanks quadrangle, Fairbanks district. At the top of Gilmore Dome.

Fairbanks quadrangle, Fairbanks district. On Monte Cristo $\mathrm{Cr}$., trib. to $\mathrm{Fish} \mathrm{Cr}$.

Fairbanks quadrangle, Fairbanks district. On Monte Cristo Crs., to $\mathrm{Fish} \mathrm{Cr}$.

Fairbanks quadrangle, Cr., trib. to Chena R., the head of Nugget $\mathrm{Cr}$. ,
Gold-quartz vein $15 \mathrm{ft}$ wide.

Several wide quartz veins.

Narrow, gold-bearing, quartz veinlets in granitic rocks.

Scheelite replacement in $1 \mathrm{imestone}$ within the Birch Creek schist formation. rmall open cut and adit of unknown length.

B. 592; 345-346.

B. $525 ; 198$.

Low-grade veins. B. 525; 210 .

Exposed in a placer cut. DMEM 1963C.

About $2000 \mathrm{ft}$ of underground workings. Production during World Wars 1 and 11 . B. 692; 325-326. B. $10241 ; 188-201$ R.I. 4174; 5-23. TDM 1943. $U$ of $A 1948$.

Scheelite in a gold-quartz vein. the spur between Melba and Fairbanks district. On Melba Cr., trib. to Fish $\mathrm{Cr}$.
B. $662 ; 412$.

Shaft $18 \mathrm{ft}$ deep. B. $662 ; 412$.

B. $592 ; 325,330-331$. ated by $3 \mathrm{ft}$ of granite. Veins consist of quartz containing gold, scheelite, bismuthinite, and tellurium.

Gold-quartz vein carrying bismuth and bismuthinite.
Reported to be rich in gold. B. $592 ; 325$. 
American claim.

Livengood quadrangle, Fairbanks district. Between Pearl Cr., trib. to Fish $\mathrm{Cr}$., and Victoria $\mathrm{Cr}$, trib. to Smallwood $\mathrm{Cr}$.

Perrault.

Fairbanks quadrangle, Fairbanks district. On the divide between Pearl $\mathrm{Cr}$. and Smallwood $\mathrm{Cr}$.

Fairbanks quadrangle, Fairbanks district. On Pearl Cr., trib. to Fish $\mathrm{Cr}$.

Livengood quadrangle, Fairbanks district. On Fish Cr., trib. to Little Chena River.

Livengood quadrangle, Fairbanks district. On Pedro Cr., trib. to Goldstream $\mathrm{Cr}$.

Fairbanks quadrangle,
Busty Belle mine. Formerly known as the Silvertone prospect and also as the Freeman and Scharf prospect.
Quartz vein 18 inches to $7 \mathrm{ft}$ wide with gold and scheelite.

70-ft shaft.

MIMI 1933; 144-145. Fairbanks district. On the divide between fox $\mathrm{Cr}$. and Flume $\mathrm{Cr}$., tribs. to Goldstream $\mathrm{Cr}$.
Three prospects: a gold-quartz vein averaging $2 \mathrm{ft}$ wide, a vein of quartz and brecciated schist averaging 18 inches wide, and a gold-bearing dike of unknown character.

Scheelite scarce and wolframite abundant in placer concentrate.

Cassiterite rare in placer concentrate.

50- $\mathrm{ft}$ shaft reported on $2-f$ vein; vein reported to have milled $\$ 24.06 *$ per ton. 60$\mathrm{ft}$ shaft on 18-inch vein, vein reported to carry $\$ 25$ = per ton in gold. Dike reported to carry $\$ 15^{*}$ per ton in gold.

B. 525; 166. B. 542 ; 151 .

B. $592 ; 329-330$.

B. 849 B; 154 .

TDM 1; 39.

TDM 1; 32.

Cassiterite rare in placer concentrate.

\section{TDM 1; 32.}

Several veins carrying gold and silver-bearing galena. Diorite wall rock.
Currently under development B.525; 198. TDM 1959. $U$ of A 1962; 121-122. 
Smith-Rowley prospect. Livengood quadrangle,

Fairbanks district. On the north side of upper Steamboat $\mathrm{Cr}$. 167 Nightingale - may now
be included in the Smith-Rowley prospect.

May Florence and Silver Dollar claims.

Birch and Anderson.

Livengood quadrangle, Fairbanks district. On Steamboat Cr., trib. to Pedro $\mathrm{Cr}$.

Livengood quadrangle, Fairbanks district. On a tributary that enters Steamboat $\mathrm{Cr}$. from the North.

Livengood quadrangle, Fairbanks district. On Granite $\mathrm{Cr}$., trib. to Pedro $\mathrm{Cr}_{\text {. }}$, $1 / 4 \mathrm{mile}$ above the road.'

Livengood quadrangle, Fairbanks district. One mile southeast of Pedro Dome.
Scheelite in schist near a

B. 10241; 209-210.

granodiorite intrusive.

Cassiterite and scheelite scarce in placer concentrate.

Flat-lying vein of silver-bearing galena in quartz-diorite.

Stibnite and galena.

Tiny veinlets of gold-bearing quartz in brecciated schist.

Three parallel, mineralized zones, 18 to $50 \mathrm{ft}$ wide, carrying goldbearing quartz, stibnite, and other sulfides.

Scheelite sparsely distributed in small pegmatite dikes. made to smelter.
TDM 1; 32, 37.

Open cuts. 2 small shipments

DMEM 1961. DMEM 1962A. DMEM $1963 A$.

B.525; 198. TDM ; 1959.

25- $\mathrm{ft}$ adit and shallow shaft. B.592; 346.

Adit $390 \mathrm{ft}$ long and a shaft. Small amount of ore reported to have milled $\$ 8 *$ per ton.

B. $520 ; 32$. 8.592; 347-348. B. $8498 ; 119-120$.

ARMI 1922; 104-105.

B. $10241 ; 210$.

R. I. 4174; 23-26.

$U$ of $A$ 1962; 122. 
$17 i \quad$ Independence mine - Livengood quadrangle, also known as the Fairbanks district. On Twin lode mine and the the east side of Twin voods mine. $\mathrm{Cr}$. below the mouth of Skoogy Gulch.

171 Burnet.

172 Moonlight group.

173 White Elephant.

North Star and North Livengood quadrangle, Star Extension - also Fairbanks district. On called the Center Star Skoogy Gulch, trib. to in some older reports. Twin $\mathrm{Cr}$.

176 Rainbow mine - also called the Rainbow and David.
Livengood quadrangle, Fairbanks district. On the ridge between Twin $\mathrm{Cr}$. and Skoogy Gulch.
Gold-quartz vein 8 to 10 inches wide with small amount of galena. Granite porphyry wall rock.

Flat-lying body of quartz in center of which are lenses of galena said to be rich in silver.

Gold-bearing vein of crushed quartz and schist 4 to 6 inches wide. A schist-granite contact crosses the workings.

Flat-lying lenses of silver-bearing galena in schist.

\section{Cassiterite common in placer} concentrate.

3-inch-wide, high-grade, gold-quart? vein.

At least 3 veins of gold-bearing quartz $1 / 2$ inch to 22 inches wide. Wallrock is schist and porphyritic granite.

Galena and sphalerite present.
Two adits and other undergrour workings. 870 tons reported to have milled $\$ 38$ per ton. B.642; 61. B.662; 410-411 B. $8498 ; 114-115$. TOM 19388 .

B.592; 349. B.849B; 118 . TDM 1959.

Three adits and other workings Grab sample \$3.26: per ton. B. $8498 ; 114$.

25- $\mathrm{ft}$ adit. Small lens of galena mined. B.592; 348. B.849B; 114 . TDM 1959.

TDM 1; 32.

45- $\mathrm{ft}$ shaft and $175 \mathrm{ft}$ of rifts. $\$ 5000^{*}$ production reported.

B.662; 409. B849B; 116-118. MIMI 1933; 135-136.

Several shafts, adits, and other workings. No production B.525; 198-200. B.542; 184-186 B. 592 ; 348. B.849B; 115-116. ARMI 1922; 104. TDM 1938B. MIMI 1933; 137-138.

B. 525; 200. 

as the Rose, also as the Mohawk.

Livengood quadrangle, Fairbanks district. Between the heads of Dome and Granite Crs. southwest of Pedro

Dome.

Livengood quadrangle, Fairbanks district. At the head of Dome $\mathrm{Cr}$. on the west side of Pedro Dome.

Livengood quadrangle, Fairbanks district.

Adjoins the Soo mine on the east.

180 Dome View. Fairbanks district. At to Little Eldorado $\mathrm{Cr}$.

Livengood quadrangle,
Three gold-quartz veins; orle 4 to 8 $\mathrm{ft}$ wide. Wide fault zone. Schist wall rock.

Two veins: one 6 to 8 inches wide and one 14 inches wide. Also a mineralized zone $14 \mathrm{ft}$ wide.

Schist wallrock; quartz-diorite intrusion nearby. wide. Quartz-mica schist wall rock. the head of the west fork of Last Chance Cr., trib. Fairbanks district. Near the head of Spruce $\mathrm{Cr}$., trib. to Little Eldorado $\mathrm{Cr}$. Location indefinite.
Gold-quartz vein 12 to 40 Inches

Stibnite lenses in a gold-quartz vein.

(n)

Nearly 100 open cuts and some underground workings. B. $525 ; 190$. B. $662 ; 407$. B. 849 B $; 81-82$.
Numerous shafts and other workings. Production about $\$ 150,000$.

B. $525 ; 190-194$. 8.542; 176180. B. 592; 342-345.

B.849B; 77-80.

ARMI 1922; 102-103.

MIMI 1933; 133-134.

TDM 1938B.

TDM 1; 10.

Shaft was being sunk in 1938 to intersect a vein that was exposed in the Soo mine. TDM 1938B.

145-ft adit. Vein probably averages $\$ 5 *$ per ton. B. 8498; 83-84.

150- $\mathrm{ft}$ shaft on lode reported to carry \$12* per ton. B. $525 ; 190.8 .542 ; 176$. 
Hidden Treasure apparently known in 1938 as the New Deal prospect.

Crayton mine - also known as the Franklin mine or the Greenback mine.

Newsboy mine.
Livengood quadrangle, Fairbanks district. At the head of Spruce $\mathrm{Cr}$.

Livengood quadrangle, Fairbanks district. Between Spruce and Eldorado Crs.

Livengood quadrangle, Fairbanks district. At the head of Whisky Gulch, trib. to Little Eldorado $\mathrm{Cr}$.

Livengood quadrangle, Fairbanks district. On Little Eldorado $\mathrm{Cr}$., trib. to Chatanika River.

Livengood quadrangle, Fairbanks district. At the main fork of Last Chance $\mathrm{Cr}$., trib. to Little Eldorado $\mathrm{Cr}$.

Livengood quadrangle, the head of Last Chance $\mathrm{Cr}$. Adjoins the Newsboy on the southwest.

Livenoood quadrangle, Fairbanks district. At

High-grade stibnite found on dump.

Stibnite body.

Gold-quartz vein carrying arsenopyrite and stibnite and stained with iron and manganese.

Cassiterite common, wolframite scarce in placer concentrate.

Mineralized fault zone with gold-quartz gash veins. Schist wall rock.

Gold-quartz vein 8 to 30 inches wide. Schist wall rock. Fairbanks district. On the divide between Cleary and Last Chance Crs.

Gold-bearing vein of crushed schist and quartz 4 to $6 \mathrm{ft}$ wide.
$161 / 2$ tons shipped in 1942. TDM 1; 10 . TDM 2; 9 .

25-ft shaft. 200 tons reported mined in 1916. B. $662 ; 415$.

Three shallow shafts, 500-ft adit, and $100 \mathrm{ft}$ of drifts. Grab sample $\$ 4.18$ per ton. B. 849B; 83. TDM 1938B.

B. $442 ; 246$. B. $379 ; 188$. TDM I; 32, 37 .

250-ft adit. Samples from a raise averaged $\$ 6$ per ton. B. 849 B; 82. B. $592 ; 342$. TDM 1938B.

Small production for several years ending in 1954. 100- $\mathrm{ft}$ shaft and $500 \mathrm{ft}$ of drifts. TOM 1952.

350-ft shaft and 4 levels. Some production.

B.525; 187-189. B.542; 172174. B.592; 340-341.

B. 849B; 85-89.

ARMI 1922; 122.

MIMI 1933; 132-133. 
Newsboy mine.

(cont.)

Westonvitch

Steil tunnel.

Tolovana mine.
Livengood quadrangle, Fairbanks district. Adjoins the Newsboy on the northeast.

Livengood quadrangle, Fairbanks district. One-half mile west of the junction of Willow and cleary Crs.

Livengood quadrangle, Fairbanks district. On the ridge between the headwater branches of Cleary $\mathrm{Cr}$.

Livengood quadrangle, Fairbanks district. West of Willow $\mathrm{Cr}$., trib. to Cleary $\mathrm{Cr}$.
Small amounts of chalcopyrite and sphalerite present in the vein.

Vein with strike different from that of the Newsboy; probably not actually an extension of the Newsboy vein.

A replacement deposit in 1 imestone within the Birch Creek schist formation; contains gold, silver, pyrite, sphalerite, galena, and stibnite.

Gold-quartz vein with stibnite and other sulfides.

Small stringer carrying large amounts of stibnite.

Lode 8 to 12 inches wide consisting of gold-bearing quartz veinlets in schist.

Fairbanks district. On Willow Cr., trib. to Cleary $\mathrm{Cr}$.

B. $525 ; 187$. B. 849 B; 89 . Co. TDM 1959.

B. $525 ; 187$.

B. $525 ; 185$. 115-ft shaft and some drifts. Reported \$15:* per ton.

B.525; 189-190. B.542; 174-1

Two adits and three shafts. Mined during World War I by the Eldorado Mining and Milli,

B662; 416. B.849B; 89-90. ARMI 1922; 101-102.

$16-\mathrm{ft}$ shaft.

About $1000 \mathrm{ft}$ of underground workings. Some production. B.525; 183-185. B.542; 169171. B.592; 339-340.

B. $8498 ; 91-92$.

ARMI 1922; 100-101

MIMI 1933; 132.

DMEM $1963 E$.

Stibnite crystals in quartz; no large masses in main vein but two other veins carry much stibnite.
B.525; 183-184.

B. $8498 ; 92$. 
Livengood quadrangle, Fairbanks district. On Willow Cr., trib. to Cleary $\mathrm{Cr}$. called the Catherine

Livengood quadrangle, Fairbanks district. At the head of Willow $\mathrm{Cr}$., trib. to Cleary $\mathrm{Cr}$.

Livengood quadrangle, Fairbanks district. At the head of Bedrock $\mathrm{Cr}$. Adjoins the Emma claim. Fairbanks district. On covered by the Jackson the divide between the claims. heads of Bedrock $\mathrm{Cr}$. and Twin $\mathrm{Cr}$.

Cleary Hill mine formerly called the Rhoads-Hall mine.
Stibnite in a wide quartz zone.

Gold-quartz vein 4 to 12 inches wide.

Unknown. Probably a lode-gold prospect.

8-to-12-inch-wide vein of galena, jamesonite, stibnite, and arsenopyrite carrying gold and silver. Also two other veins. Schist wallrock.

Cassiterite common and scheelite scarce in placer concentrate.

Gold-quartz vein 4 to 24 inches wide. Schist wall rock.

Cassiterite and scheelite in the vein.

Bunches of stibnite in the vein.

$-46-$
Discovered in 1942 in a placer cut.

TDM 2; 7.

60- $\mathrm{ft}$ shaft and $100 \mathrm{ft}$ of drifts. 10 tons reported to have milled $\$ 38 *$ per ton. B. 525 ; 185-186. B.542; 171172. B. 592; 340 .

B. 8498; $90-91$.

Adit and shallow shafts.

No recent work has been done on the prospect.

B. $8498 ; 91$.

Open cuts and some undergrounc workings. About 35 tons mine and shipped during 1952 - 195 : B592; 338. B.662; 416-417.

B. 849B; 92-93.

TDM 1959.

TDM 1; 32, 37.

Extensive underground working! Production more than $\$ 1,000,00$ B. 525; 177-180. B.542; 163166. B. 592; 337-338.

B. 849B; 93-96.

ARMI 1922; $98-100$.

MIMI 1933; 130-131.

TDM 1938B.

B.649; 35. B.10241; 208-209.

Production of stibnite in 1942 TDM 2; 9. 
Livengood quadrangle, Fairbanks district. On the east side of Bedrock $\mathrm{Cr}$. Adjoins the Cleary Hill mine on the south.

B.P. claim.

Union mine.

Scott Reese tunnel on the Rex claim.

Bobbie claim.

Colbert and Warmbold.

Livengood quadrangle, Fairbanks district. On the west side of Chatham $\mathrm{Cr}$. 1/2 mile from Cleary Cr.

Livengood quadrangle, Fairbanks district. On Cleary Hill property.

Livengood quadrangle, Fairbanks district. On the west side of Chatham $\mathrm{Cr} .200 \mathrm{ft}$ south of the B.P. workings.

Livengood quadrangle, Fairbanks district. West of the junction of Chatham and Tamarack Crs.

Livengood quadrangle, Fairbanks district. At
Chatham $\mathrm{Cr}$. adjoining the the head of Tamarack $\mathrm{Cr}$. trib. to Chatham $\mathrm{Cr}$. also a vein consisting of stibnite
Three gold-quartz veins 1 to $2 \mathrm{ft}$ wide. One may be the extension of the Cleary Hill vein. Schist wall rock.

Cassiterite and scheelite present in the vein.

Gold-quartz vein with stibnite and other sulfides.

Shear zone carrying free gold, galena, stibnite, and sphalerite.

About $800 \mathrm{ft}$ of underground workings. Some production. B. 525; 181-182.

B. 542; 166-168. B592; 338 . B. 8498; 96-98.

ARMI 1922; 100.

B. 10241; 206-208.

B592; 337.

Unknown.

Two narrow gold-quartz veins.

Schist wall rock.

Small vein of nearly pure galena, and galena.

Gold-quartz vein 5 inches wide.
90- $\mathrm{ft}$ adit and 150- $\mathrm{ft}$ winze with short drifts.

B. $525 ; 176$. B. $542 ; 162-163$. B849B; 98. B.649; 35 .

25 tons selected from dump averaged $\$ 22$ per ton.

TDM 1938B.

$320-\mathrm{ft}$ adit.

B849B; 98-99.

MIMI 1933; 137. TDM 1938B.

Inclined shaft and open cuts. B525; 177, 182. B.542; 163. B.649; 35. TDM 1959 .

240-ft adit. MIMI 1933; 130. 
Livengood quadrangle, Fairbanks district. On

Chatham $\mathrm{Cr}$. between

the Pioneer and the

Chatham Mine.

\section{Pioneer (North Star} claim)
Livengood quadrangle, Fairbanks district. On Chatham $\mathrm{Cr}$. $1 / 4$ mile below Tamarack $\mathrm{Cr}$.

Livengood quadrangle, Fairbanks district. On Chatham $\mathrm{Cr}$.; location indefinite.
Two lodes; one 4 to $8 \mathrm{ft}$ wide carries arsenopyrite and silverbearing galena.

Gold and stibnite lode.

Flat-lying, gold-quartz vein.

Quartz vein $3 \mathrm{ft}$ wide intersected by a smaller vein. Both veins carry free gold; smaller vein also carries stibnite, arsenopyrite and sphalerite.

1-ft-wide vein of stibnite.

Stibnite float noted in dredge tailings.

One vein 18 inches wide; sample reported $\$ 40 *$ per ton. One vein 8 to 10 inches wide; sample reported $\$ 16.88 \div$ per ton. One vein 3 to $5 \mathrm{ft}$ wide.
Several shallow shafts.

Channel sample $\$ 0.46 *$ per ton B. 849B; 100. TDM 1959.

Production in 1916 and 1942 . B. $525 ; 172$. B. $542 ; 158-159$. B. $592 ; 335-336$. B.662; 415 . B. $8498 ; 100-101$.

TDM 2; 8-9.

ARMI 1922; 97-98, 110.

MIMI 1933; 129-130.

TDM 1938B.

$125-\mathrm{ft}$ shaft and $112 \mathrm{ft}$ of drifts. Small production $\$ 30 *$ per ton reported. B. 525; 175. B.542; 160 . B. $592 ; 337$.

85- $\mathrm{ft}$ shaft and $92-\mathrm{ft}$ shaft $\$ 30 *$ to $\$ 90 *$ per ton reported from milling.

B. 525; 173-174. B.542; 159160. B.592; 336. B.849B; 99. MIMI 1933; 131 . ARMI 1922; 98.

B. $314 ; 30$.

TDM 2; 9.

$125-\mathrm{ft}$ shaft and $112 \mathrm{ft}$ of drifts.

B849B; 99-100. 
Livengood quadrangle, Fairbanks district. On

Chatham Cr., trib. to

Cleary $\mathrm{Cr}$.

Harris and Brown.

217 Quemboe.

Shelden-Vetter.

219 Homes take.
Livengood quadrangle, Fairbanks district. On Cleary Cr., trib. to

Chatanika River.

Livengood quadrangle, Fairbanks district. On the ridge between Wolf and Chatham Crs.

Livengood quadrangle, Fairbanks district. On the west slope of Wolf Cr. valley.

Livengood quadrangle, Fairbanks district. On the Wolf $\mathrm{Cr}$. side of the Wolf $\mathrm{Cr}$.-Chatham $\mathrm{Cr}$. divide.

Livengood quadrangle, Fairbanks district. Adjoins the Homestake on the west.

Livengood quadrangle, Fairbanks district. At the head of Wolf $\mathrm{Cr}$.
Cassiterite and scheelite common in placer concentrate.

TDM $1 ; 32,37$.

At least 5 veins. Schist wallrock.
Cassiterite and scheelite common in placer concentrate.

Gold-quartz vein with stibnite and other sulfides.

50-ft shaft.

B. $525 ; 175-176$.

3-4-inch quartz vein with large

amount of stibnite.

Gold-quartz with stibnite, pyrite, and arsenopyrite. Schist wall rock.

Gold-quartz vein in schist, also silver-bearing galena.

TDM $1 ; 32,37$.

B. $525 ; 171$

60-ft shaft and short drift Samples reported $\$ 22.50 \div$ pe ton and $\$ 32 *$ per ton.

B. 525; 171-172. B.542; 158

Shallow shaft and open cuts Production during 1963-1965 TDM 1959

$U$ of A 1962; 117-121.

750-ft adit. $\$ 60,000 *$ produced.

B. $525 ; 168$. B.542; 153-155

B. $592 ; 331-334$.

B. 662 ; 406-407.

B. 849B; $101-102$.

ARMI 1922; 96-97.

Small amounts of chalcocite present. B.592; 334 

the Homestake)

220 Pennsylvania claim (now part of the McCarty group)

Pioneer claim (now part of the McCarty group)

\section{McCarty mine or} group. (includes the Rexall mine, Pioneer claim, Henry Ford group, and War Eagle group)
Livengood quadrangle, Fairbanks district. At the head of Wolf $\mathrm{Cr}$., trib. to Cleary $\mathrm{Cr}$.

Livengood quadrangle, Fairbanks district. At the crest of the divide between Fairbanks and Wolf Crs.

Livengood quadrangle, Fairbanks district. At the crest of the divide between Fairbanks and Wolf Crs.

Livengood quadrangle, Fairbanks district. At the head of Fairbanks $\mathrm{Cr}$.
Lenses of stibnite with high lead content.

Two intersecting veins; one $5 \mathrm{ft}$. wide and one 12 to 18 inches wide.

Gold quartz vein 18 inches wide.

Gold-quartz vein and stibnite vein in schist.

Several gold-quartz veins in schist.

Stibnite in the veins.
8.592; 334. B. $662 ; 407$. TDM $2 ; 8$.

Adit with about $900 \mathrm{ft}$ of workings.

B. 525; 168-171. B. 542; 155-

157. B. B92; 334-335.

B. $8498 ; 100-101$

ARMI 1922; 95-96.

146-ft shaft and drifts. $\$ 10,000 *$ production reported B. 525; 167. B.542; 151-152. B. 592 ; 331. B. 849 B; 102-103 ARMI 1922; 97.

110-ft shaft, 75-ft shaft, and 38-ft shaft. 107 tons yielded $\$ 125^{\star}$ to $\$ 172^{*}$ per ton.

B. $525 ; 165$. B. $542 ; 150$. B. 849B; 102-103. DMEM 1960.

Shafts and extensive underground workings. Production until 1942.

B. 592; 326. B.662; 411-412. B. 849B; 102-113. MIMI 1933; 135.

TDM 1938B.

Production during World War and World War 11.

B.8498; 102-103. TDM 1; 10. TDM; 7-8. TDM 1960. 
Livengood quadrangle, Fairbanks district. On Fairbanks $\mathrm{Cr}$. below the McCarty mine.

223 Mizpah. Fairbanks district. On the ridge I mile westnorthwest of the mouth of Too Much Gold Cr., trib. to Fairbanks $\mathrm{Cr}$.

Livengood quadrangle, Fairbanks district. West of Too Much Gold $\mathrm{Cr}$. and east of the Mizpah.

Livengood quadrangle, Fairbanks district. West of Too Much Gold $\mathrm{Cr}$.

Livengood quadrangle, Fairbanks district. North of Fairbanks $\mathrm{Cr}$. and west of Too Much Gold $\mathrm{Cr}$.

227 Excelsior claim.

Lode of quartz veinlets carrying
Galena and stibnite in the vein.

Several gold-quartz veins, relationships obscure.

Low-grade gold lode consisting of quartz stringers in schistose quartzite.

Stibnite in irregular patches in quartz stringers.

Vein of crushed, iron-stained quartz 20 to 24 inches wide, carrying gold and sulfides.

Kidney-shaped mass of stibnite 12 to 15 inches wide on the Early Bird claim; also stibnite and galena in other veins. gold and silver; some carry stibnite. B.592; 329.

Quartz vein 6 inches wide carrying gold and scheelite. Schist wall rock. B.10241; 208.

Small gold-quartz veins with galena, arsenopyrite, and stibnite. High silver assays reported from graphitic schist. 80-ft adit. B. $525 ; 163,164$.

B. $525 ; 164$.

Shaft more than $80 \mathrm{ft}$ deep and at least $170 \mathrm{ft}$ of drift Production said to have averaged $\$ 30^{*}$ to $\$ 40 *$ per to B. 525; 162. B.542; 147-148. B. $592 ; 329$. B. $662 ; 405-406$. B. $8498 ; 107$. ARMI 1922, 95.

B. $662 ; 405-406$.

240- $\mathrm{ft}$ adit. 350 tons mined B. $525 ; 162-163$. B. $542 ; 148$. B. $662 ; 408-409$. B. 8498 ; 107 . 108.

ARMI 1922; 94-95.

B. $525 ; 162-163$. B. $662 ; 409$.
Livengood quadrangle, Fairbanks district. On Too Much Gold $\mathrm{Cr}$.
Two adits. More than $60 \mathrm{ft}$ workings.

B.525; 161 . 
Nars, Anderson, and Gibbs.

McNeil shaft.

Governor claim.

Hi-Yu mine -

(formerly called the Crites and Feldman mine)
Livengood quadrangle, Fairbanks district. On upper Too Much Gold $\mathrm{Cr}$. above the Excelsior claim.

Vein of unknown width carrying galena, stibnite, and arsenopyrite.

Open pits only. B. 525; 161-162.

Too gold-quartz veins either the same as, or parallel to, the $\mathrm{Hi}-\mathrm{Yu}$ veins.

Fairbanks district. At the head of Too Much Gold $\mathrm{Cr}$.

Livengood quadrangle, Fairbanks district. At the head of the west fork of Too Much Gold $\mathrm{Cr}$.

Livengood quadrangle, Fairbanks district. Between Too Much Gold and Moose Crs.

Livengood quadrangle, Fairbanks district. On the ridge between loose $\mathrm{Cr}$. and Too Much Gold Cr., tribs. to Fairbanks $\mathrm{Cr}$. from mill tests.

Gold-quartz vein with sulfides. Schist wall rock. Jamesonite and galerra found in sacks near the shaft.

Gold-bearing vein. Vein material includes a light-colored, finegrained rock, probably granite.

Three nearly parallel gold-quartz veins up to $3 \mathrm{ft}$ wide. $100-\mathrm{ft}$ shaft and $40 \mathrm{ft}$ of drifts. $\$ 60 *$ per ton reporte

B. $525 ; 159$. B. $542 ; 144$.

B. $592 ; 328-329$. B. $662 ; 407-40$

Small amounts of galena and sphalerite in the veins.

Stibnite in the veins and also a stibnite body discovered in 1941 $1 / 4$ mile northwest of the mine portal.
Shaft of unknown depth. B.849B; 104. DMEM 1963F.

70-ft shaft. Reported to carry $\$ 10^{*}$ to $\$ 15^{*}$ per ton in gold.

B. $525 ; 160$. B. $542 ; 145$.

Extensive workings for $7000 \mathrm{f}$ along the vein system. Inter mittent production over a 30-yr period ending in 1942. B. 525; 156-158. B.542; 142144. B. 592; 327-328.

B. $662 ; 404-405$. B. 849 B; 108113.

ARMI 1922; 91-93.

MIMI 1933; 134-135.

TDM 1938 .

B. $525 ; 158$.

15 tons mined in 1952. B. 525; 157-158. TDM 2; 7 . 
Livengood quadrangle, Fairbanks district. On the east side of Too Much Gold $\mathrm{Cr}$.

234 Lime-Lemon, North Star, and Eureka claims - also called the McCarthy property.

Queen claim.

Egan prospect.

Livengood quadrangle, Fairbanks district. At the head of Alder $\mathrm{Cr}$. trib. to Fairbanks $\mathrm{Cr}$.

Livengood quadrangle, Fairbanks district. Between Alder and Crane Crs., tribs. to Fairbanks $\mathrm{Cr}$.

Livengood quadrangle, Fairbanks district. Between the headwater forks of Kokomo $\mathrm{Cr}$., trib. to Chatanika R.

Livengood quadrangle, Fairbanks district. On the southwest side of Coffee Dome at the head of Walnut Cr., trib. to Fairbanks Cr.

Livengood quadrangle,
Brecciated mass of rock cemented by iron, stibnite, and galena.

Gold-quartz vein 12 to $13 \mathrm{ft}$ wide. Fairbanks district. On Fairbanks $\mathrm{Cr}$.,trib. to Fish $\mathrm{Cr}$.

Gold-quartz vein 18 inches wide.

Four or five gold-bearing veins in biotite schist.

Primarily a silver prospect; vein 18 inches wide with sulfides.

Cassiterite and scheelite common, wolframite scarce in placer concentrate.
B. $525 ; 160$.

50- $\mathrm{ft}$ shaft. Some productio B. 525 ; 156. B. 542; 141-142.

100-ft shaft.

B. $592 ; 326$.
Two shafts $15 \mathrm{ft}$ deep and op pits. Sample across 20-inch wide vein assayed $\$ 7.38$ per ton.

B. 8498 ; 155. TDM 1938B.

50- $\mathrm{ft}$ shaft. Some productio B. $520 ; 31$. B. $542 ; 141$.

B. $442 ; 246$. TDM 1; $32,37$. 
B.824 - Mineral Resources of Alaska, Report on Progress of Investigations in 1929, by P.S. Smith and others. 1932. 181 pp.

B. 8440 - Mineral Deposits of the Rampart and Hot Springs Districts, Alaska, by J.B. Mertie, Jr.; Placer Concentrates of the Rampart and Hot Springs Districts, by A.E. Waters, Jr. 1934. 83 pp.

B.849B - Lode Deposits of the Fairbanks District, Alaska, by J.M. Hill. 1933. $134 \mathrm{pp}$.

B.872 - The Yukon-Tanana Region, Alaska, by J.B. Mertie, Jr. 1937. 276 pp.

B.880A - Mineral Industry of Alaska in 1935, by P.S. Smith. 1937. 95 PP.

B.897C - Gold Placers of the Fortymile, Eagle, and Circle Districts, Alaska, by J.B. Mertie, Jr. 1938. 128 pp.

B.917A - Mineral Industry of Alaska in 1938, by P.S. Smith, 1939. 113 pp.

B.926C - Occurrences of Molybdenum Minerals in Alaska, by P.S. Smith 1942. 59 pp.

B.10241- Tungsten Deposits in the Fairbanks District, Alaska, by F.M. Byers,Jr. 1957. 37 pp.

\section{U.S. Geological Survey Circulars}

C.331 - Reconnaissance for Radioactive Deposits in Eastern Interior Alaska, 1946, by Helmuth Wedow, Jr., P.L. Killeen, and others. 1954. 36 pp.

C. 335 - Reconnaissance for Radioactive Deposits in East-Central Alaska, 1949, by Helmuth Wedow, Jr., M.G. White, and others. 1954. 22 pp.

C.348 - Reconnaissance for Radioactive Deposits in Eastern Alaska, 1952, by A.E. Nelson, W.S. West, and J.J. Matzko. 1954. 21 pp.

\section{U.S. Bureau of Mines Reports of Investigations}

R.1.4173 Antimony Deposits in Alaska, by Norman Ebbley, Jr., and W.S. Wright. 1948. $41 \mathrm{pp}$.

R.1.4174 Tungsten Deposits in Alaska, by Robert L. Thorne, Neal M. Muir, Aner W. Erickson, Bruce 1. Thomas, Harold E. Heide, and Wilford S. Wright, 1948. $51 \mathrm{pp}$.

R.1.5373 Tin-Bearing Placer Deposits near Tofty, Hot Springs District, Central Alaska, by Bruce 1. Thomas. 1957. 56 pp. 


\section{University of Alaska Theses}

$U$ of A 1931 - An Investigation of the Gold-Bearing Quartz Veins of Ester Dome, by Robert James McCombe and Grant Augustine, Jr. 1931.

$U$ of A 1948 - Scheelite Deposits of the Fairbanks District, Alaska, by Stanley Lefond. 1948.

$U$ of A 1951 - Relations of Structure to Mineral Deposition at the Grant Mine, Ester Dome, Alaska, by Peter 0. Sandvik and Allan J. Hersey. 1951.

U of A 1962 - Bedrock Geology and Ore Deposits of the Pedro Dome Area, Fairbanks Mining District, Alaska, by Jim M. Brown. 1962.

Published Reports of the Division of Mines and Minerals and its Precedent Agencies.

ARMI 1922 - Annual Report of the Mine Inspector to the Governor of Alaska, 1922, by B.D. Stewart. 175 pp.

MIMI 1933 - Mining Investigations and Mine Inspection in Alaska, Biennium Ending March 31, 1933, by B.D. Stewart. 192 pp.

Geochem. Rept. 3 - A Geochemical Investigation in the Richardson Area, Big Delta Quadrangle, Alaska, by R.H. Saunders. 1965. 12 pp.

Geochem Rept. 12 - A Geochemical Investigation of Minoor: Creek, Rampart District, Alaska, by W.M. Burand and R.H. Saunders. 1966. 15 pp.

TDM 1 - Pamphlet No. I, Strategic Mineral Occurrences in Interior Alaska, by H.R. Joesting. 1942. 46 pp.

TDM 2 - Pamphlet No. 2, Supplement to Pamphlet No. 1, Strategic Mineral Occurrences in Interior Alaska, by H.R. Joesting. 1943. 28 pp.

Ann. Rept. 1961 - Report of the Division of Mines and Minerals for the year 1961. $108 \mathrm{pp}$.

Ann. Rept. 1962 - Report of the Division of Mines and Minerals for the year 1962. $119 \mathrm{pp}$.

\section{Other Publications}

MWRA - Mineral and Water Resources of Alaska, Report Prepared by the United States Geological Survey in Co-operation with the State of Alaska Department of Natural Resources at the Request of Senator Ernest Gruening of Alaska of the Committee on Interior and Insular Affairs, United States Senate. 1964. $179 \mathrm{pp}$. 
Unpublished Reports by the Division of Mines and Minerals and its Precedent Agencies.

TDM 1937 - Brief Report on the Goodpaster Quartz-Lode Mining at the Head of Johnson and Boulder Creeks, by Irving Reed. 1937. I p.

TDM 1938A - Mining and Prospecting in the Goodpaster Region, by H.R. Joesting. 1938. 2 pp.

TDM 1938B - Report on Lode Mining and Development in the Year 1938 in the Fairbanks District, Alaska, by Irving Reed. 1939. 27 pp.

TDM 1941 - Mining and Prospecting in the Fairbanks Precinct during 1941 , by H.R. Joesting. $1 \mathrm{p}$.

TDM 1942 - Preliminary Report on the My Creek Stibnite Prospect, Fortymile District, Alaska, by H.R. Joesting. 1942. 2 pp.

TDM 1943 - Preliminary Report on Scheelite Deposits in the Fairbanks District, Alaska, by H.R. Joesting and Eskil Anderson. 1943. 10 pp.

TDM 1951 - Examination of Prospect Trenches on Ready Bullion Lode Property, by James A. Williams. 1951. 4 pp.

TDM 1952 - Electrical Resistivity Survey at the Crayton Mine, Pedro Dome, 1952 , by R.H. Saunders. 2 pp.

TOM 1953 - Report on Preliminary Examination of the Fred J. Jenkins Property Near Eagle, Alaska, by R.H. Saunders. 1953. 14 pp.

TDM 1954A - Report on the Vuyovich Gold-Quartz Prospect, Ester, Alaska, by R.H. Saunders. 1954. 7 pp.

TOM 1954B - Report on the Examination of the Ricks Prospect, Big Delta Quadrangle, Alaska, by R.H. Saunders. 1954. 8 pp.

TDM 1955 - Report on the Griffin Nickel Prospect, Livengood Quadrangle, by R.H. Saunders. :955. 4 pp.

TDM 1956A - Report on the Flume Creek Lode-Gold Prospect, Eagle Quadrangle, by R.H. Saunders. 1956. 6 pp.

TDM 1956B - Report on the Examination of the Copper Creek Copper Prospect, Eagle Quadrangle, by R.H. Saunders. 1956. 6 pp.

TDM 1956C - Notes on the Occurrence of Cinnabar at Canyon Creek, Eagle Quadrangle, Alaska, by R.H. Saunders. 1956. 3 pp.

TDM 1957A - Work Done in 1957 on the Vuyovich Gold-Quartz Prospect, Fairbanks Quadrangle, by R.H. Saunders. 1957. 2 pp.

TDM 1957 B - Supplementary Report on the Ready Bullion Lode Prospect, Fairbanks District, by R.H. Saunders. 1957. 2 pp. 
TDM 1957C - Report on Scheelite-Bearing Veins at the Weston Placer Mine, Eagle Quadrangle, by R.H. Saunders. 1957. 4 pp.

TDM 19570 - Work Done in 1956-57 on the Spruce Hen Tungsten Prospect, Fairbanks Quadrangle, by R.H. Saunders. 1957. 2 pp.

TDM $1957 E$ - Report on the La Flamme Copper Prospect, Eagle Quadrangle, by R.H. Saunders. 1957. 3 pp.

TDM 1958 - Report on the Sawtooth Mountain Antimony Prospect, Livengood Quadrangle, by R.H. Saunders. 1958. 6 pp.

TOM 1959 - Silver-Lead Occurrences in the Fairbanks District, by R.H. Saunders. 1959. 8 pp.

DMEM 1960A - Report on the Purdy Gold-Quartz Prospect, Eagle Quadrangle, by R.H. Saunders. 1960. 2 pp.

DMEM 1960B-- Notes to Accompany Prospect Map of the Fairbanks-Wolf Creek Divide, by R.H. Saunders. 1960. 3 pp.

DMEM 1961 - Report on the Preliminary Examination of a Prospect on Steamboat Creek, Fairbanks District, Livengood Quadrangle, by R.H. Saunders. 1961. 3 pp.

DMEM 1962A - Sampling and Geochemical Prospecting at Steamboat Creek, Fairbanks District, 1961, by R.H. Saunders. 1962. 5 pp.

DMEM 19628 - My Creek and Our Creek Silver Prospects, Fortymile District, Eagle Quadrangle, by R.H. Saunders. 1962. 7 pp.

DMEM 1962C - Report on the Examination of the Mitchell Copper Prospect, Eagle Quadrangle, by R.H. Saunders. 1962. 4 pp.

DMEM 1963A - Work at the Steamboat Creek Prospect, Fairbanks District, in 1963, by R.H. Saunders. 1964. 6 pp.

DMEM 1963B - Work at the Vuyovich Prospect, Fairbanks Quadrangle, in 1963, by R.H. Saunders. 1964. 3 pp.

DMEM 1963C - Examination of a Gold Prospect on Nugget Creek, Fairbanks Quadrangle, by R.H. Saunders. 1963. 3 pp.

DMEM 19630 - The McGrath Lode-Gold Prospect, Fairbanks Quadrangle, by R.H. Saunders. 1963. 3 pp.

DMEM 1963E - Report on the Examination of Trenches at the Tolovana Mine, Livengood Quadrangle, by R.H. Saunders. 1963. 3 pp.

DMEM 1963F - Examination of Trenches on the Fairbanks-Wolf Creek Divide, by R.H. Saunders. 1963. 4 pp. 


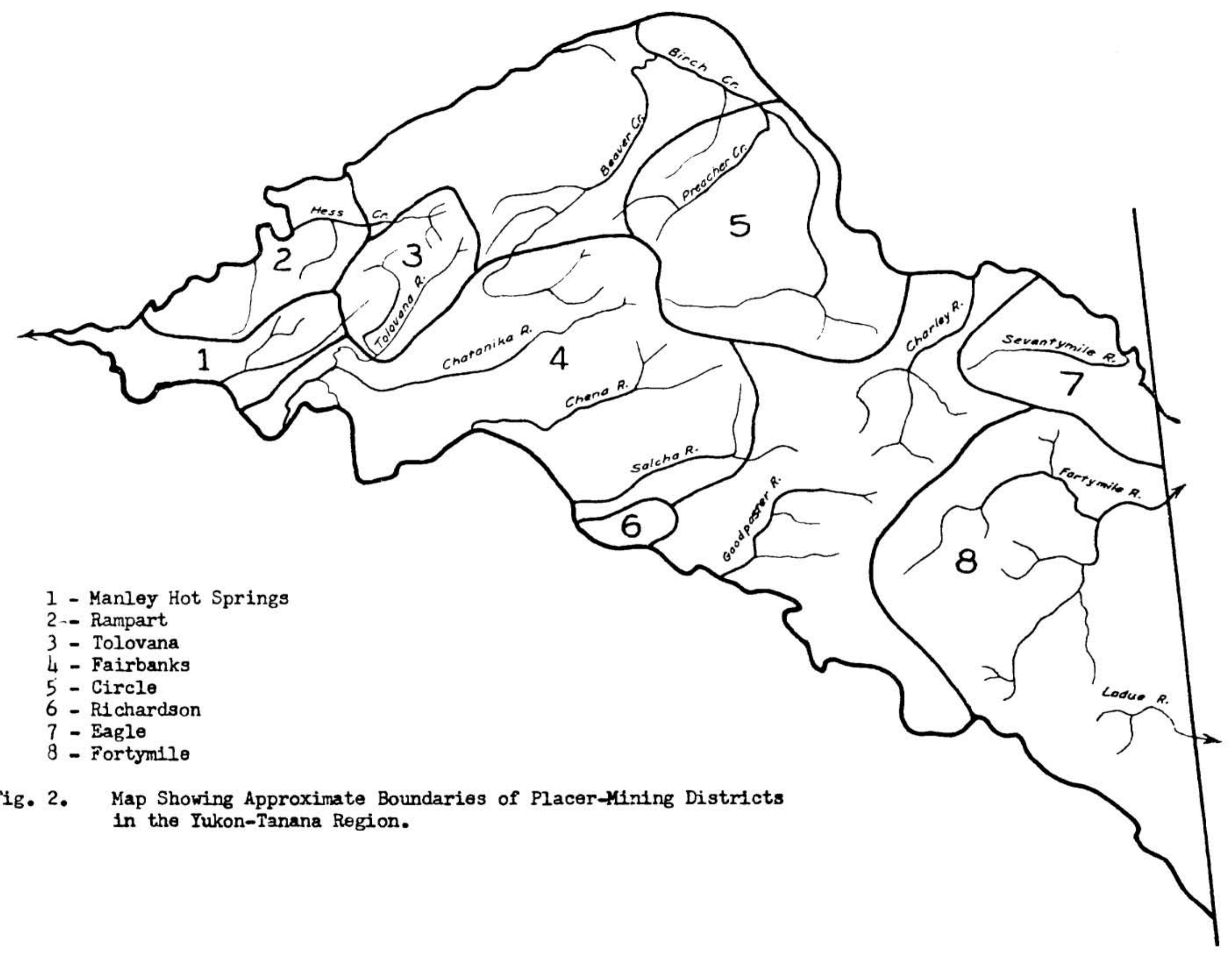




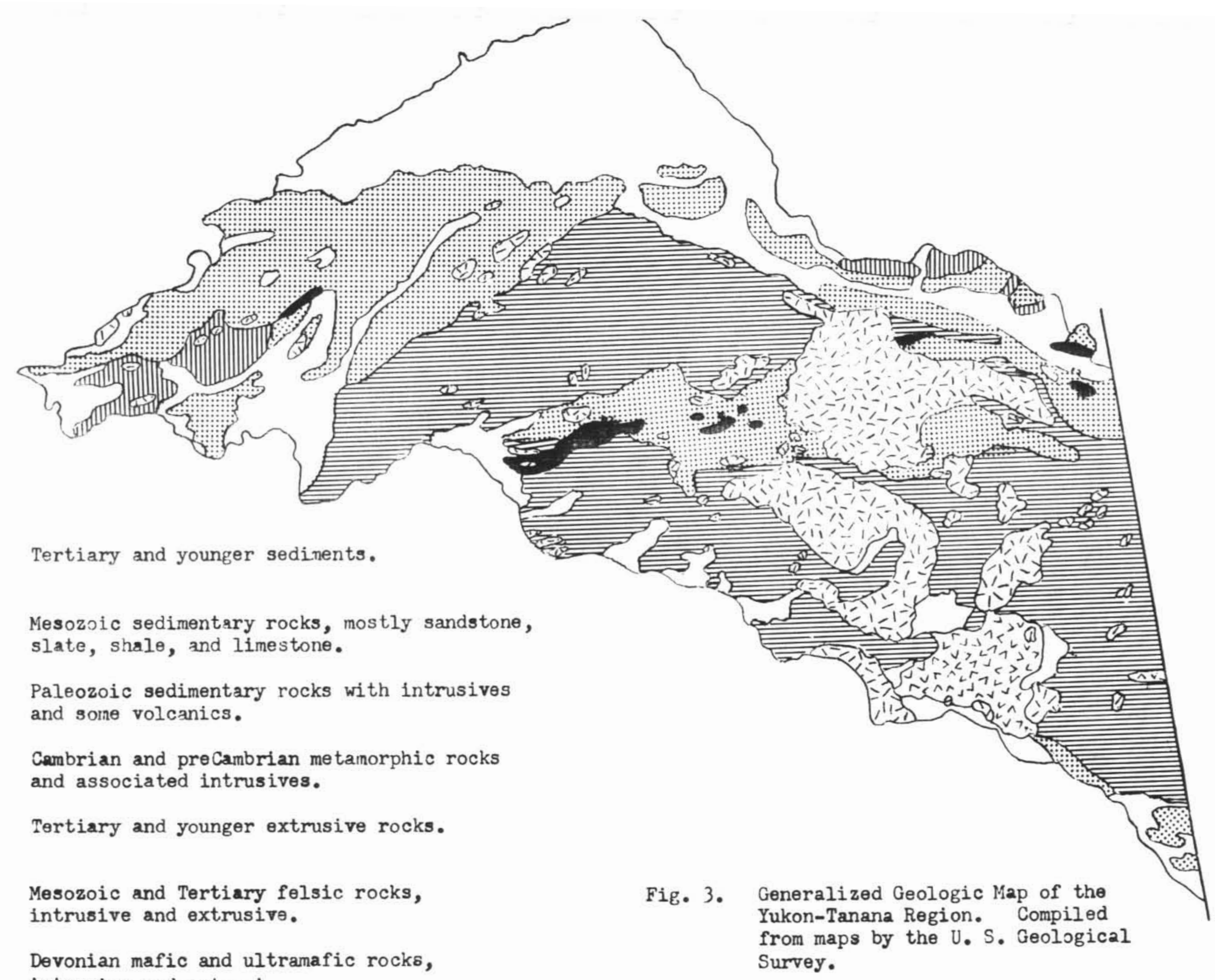
intrusive and extrusive. 